\title{
INFLUENCE OF DIFFERENT $\mathrm{CaF}_{2}$ CONTENTS AND HEAT TREATMENT TEMPERATURES ON APATITE-MULLITE GLASS CERAMICS DERIVED FROM WASTE MATERIALS
}

\author{
WAN NURSHAMIMI WAN JUSOH*, "KHAMIRUL AMIN MATORI*,**, MOHD HAFIZ MOHD ZAID*, NORHAZLIN \\ ZAINUDDIN***, MOHAMMAD ZULHASIF AHMAD KHIRI**, \\ NADIA ASYIKIN ABDUL RAHMAN*, ROHANIAH ABDUL JALIL*, ESRA KUL**** \\ *Department of Physics, Faculty of Science, Universiti Putra Malaysia, 43400 UPM Serdang, Selangor, Malaysia \\ **Material Synthesis and Characterization Laboratory, Institute of Advanced Technology, Universiti Putra Malaysia, \\ 43400 UPM Serdang, Selangor, Malaysia \\ ***Department of Chemistry, Faculty of Science, Universiti Putra Malaysia, 43400 UPM Serdang, Selangor, Malaysia \\ ****Department of Prosthodontics, Faculty of Dentistry, Ataturk University, 25030 Erzurum, Turkey \\ "E-mail: khamirul@upm.edu.my
}

Submitted November 6, 2019; accepted April 9, 2020

\begin{abstract}
Keywords: Apatite-mullite glass ceramics, $\mathrm{CaF}_{2}$, Clam shell, Heat treatment, Soda lime silicate glass
An apatite-mullite glass ceramics composition derived from clam shell (CS) and soda lime silicate (SLS) glass has been fabricated from a heat treatment process of composition, $\left[x \mathrm{CaF}_{2} \cdot(45-x) \mathrm{SLS} \cdot 15 \mathrm{CS} \cdot 20 \mathrm{Al}_{2} \mathrm{O}_{3} \cdot 20 \mathrm{P}_{2} \mathrm{O}_{5}\right]$, where $x$ is $5,10,15$ and 20 (wt. \%). The result concluded that the Ca and Si elements were found in the CS and SLS glass respectively as a major weight composition, thereby promoting the use of waste materials in the manufacture of glass ceramic samples. Besides, the $\mathrm{CaF}_{2}$ addition lowers the glass transition temperature $\left(T_{g}\right)$ and crystallisation temperature $\left(T_{c}\right)$ of the glass composition. The density and percentage of the linear shrinkage of the samples differs with the addition of $\mathrm{CaF}_{2}$ and various heat treatment temperatures. For the structural properties' analysis, the formation of fluorapatite with a needle-like microstructure and mullite phase was enhanced with a higher $\mathrm{CaF}_{2}$ content, while the growth of the anorthite phase was observed to occur at a higher heat treatment temperature. Generally, the addition of ahigh $\mathrm{CaF}_{2}$ content with the help of heat treatment in apatitemullite glass ceramics composition greatly promotes the crystallisation of the fluorapatite phase, which is crucial for denture glass ceramics.
\end{abstract}

\section{INTRODUCTION}

Dental glass ceramics are a type of biomaterial that are mainly focused in the restoration and reconstruction of teeth. The use of denture glass ceramics in the dental materials market, especially as implants, dental cements, restorative materials and others [1-3], has become a main concern since glass ceramic materials have superior properties, such as being easy to process, have good chemical durability, excellent aesthetics, translucency, low thermal conductivity, high strength and hardness, biocompatibility and also wear resistance, same to that of the original teeth $[4,5]$. Designing glass ceramic materials by controlling the heat treatment process and glass composition itself may alter the properties which are very important to produce the desired dental materials.

A type of glass ceramics system known as apatitemullite glass ceramics has attracted great attention for researchers since it reassuring good use in a glass ionomer cement or being well known as a glass polyalkenoate cement as a base powder. Aluminosilicate glass composition which usually consists of $\mathrm{CaO}-\mathrm{SiO}_{2}-\mathrm{P}_{2} \mathrm{O}_{5}-$ $-\mathrm{Al}_{2} \mathrm{O}_{3}-\mathrm{CaF}_{2}$ was found to produce an apatite-mullite crystal phase [6-13]. The formation of the apatite-mul- lite crystal phase is important since it exhibits good mechanical properties especially in terms of strength and fracture toughness resulting from the bulk nucleation and crystallisation process of the glass composition, which is suitable for dental applications [3, 14].

In a glass system, the role of a network former, network modifiers and intermediate oxides are crucial for designing the glass composition which suits the desired applications [2]. Network forming oxides such as $\mathrm{SiO}_{2}$ and $\mathrm{P}_{2} \mathrm{O}_{5}$, responsible in increasing the network connectivity which cause two neighbouring polyhedrals to join together, thus increasing the surface reactivity of the glass composition [15]. $\mathrm{CaO}$ acts as modifying oxide which depolymerises the glass network to nucleate the apatite layer formation and enhance the crystallisation, meanwhile $\mathrm{Al}_{2} \mathrm{O}_{3}$ is an intermediate oxide which can inhibit the bonding in the glass network [2].

$\mathrm{CaF}_{2}$, as a nucleating agent, plays an important role in the aluminosilicate glass composition where it promotes the growth of the fluorapatite and mullite crystal phase, therefore, increasing the strength of the material $[8,16]$. In addition, $\mathrm{CaF}_{2}$ is also responsible for enhancing the crystallisation kinetics, which allow particle movement and the reordering of the glass network, thus causing the 
phase separation to occur $[6,17]$. Besides, the fluoride ion contained in the structure of $\mathrm{CaF}_{2}$ is responsible for encouraging the remineralisation, which is important in preventing tooth decay. In the remineralisation process, the $\mathrm{OH}^{-}$ion is replaced by the $\mathrm{F}^{-}$ion in order to form apatite, thus creating an improved tooth mineral quality $[18,19]$.

Limited studies in the fabrication of glass ceramics from waste materials such as clam shell (CS), fly ashes, rice husks, soda lime silicate (SLS) glass and others have encouraged researchers to investigate the properties of the glass ceramics fabricated from these industrial waste materials [20-24]. Such raw materials provide chemical substances for the glass composition. For example, silicate and calcite can be derived from SLS glass and $\mathrm{CS}$, respectively. Thus, the utilisation of waste materials in the production of glass ceramics is not only effective in saving the production costs, but can reduce the environmental issues regarding the disposal problems.

The overall goal for this study is to fabricate an apatite-mullite glass ceramics composition from waste materials. Besides, the influence of the $\mathrm{CaF}_{2}$ content and the different heat treatment temperatures on the thermal, physical and structural properties of the apatite-mullite glass ceramics derived from the CS and SLS glass has also become a main aim for this investigation.

\section{EXPERIMENTAL}

\section{Sample preparation}

The 'Anadara Granosa' species CS and commercial SLS glass bottles, which are the waste materials used, were collected and cleaned before the CS was calcined at $900{ }^{\circ} \mathrm{C}$ for 2 hours in an electrical furnace. On the other hand, the SLS glass was crushed using a hammer to produce glass pieces before being milled in milling jar. The milling jar was filled with 20 milling balls which help in the production of SLS glass powders. After that, both the CS and SLS glass powder were sieved using a $45 \mu \mathrm{m}$ sized sieve and ground using a mortar and pestle until a fine powder was formed. The chemical powders, which are $\mathrm{P}_{2} \mathrm{O}_{5}\left(99.99 \%\right.$, Alfa Aesar), $\mathrm{Al}_{2} \mathrm{O}_{3}(99.5 \%$, Alfa Aesar) and $\mathrm{CaF}_{2}$ (99.95\%, R\&M Chemicals) were used in the glass powder formulation. The formulation of the aluminosilicate glass composition has the formula, $\left[x \mathrm{CaF}_{2} \cdot(45-x) \mathrm{SLS} \cdot 15 \mathrm{CS} \cdot 20 \mathrm{Al}_{2} \mathrm{O}_{3} \cdot 20 \mathrm{P}_{2} \mathrm{O}_{5}\right]$, where $x=5$, 10,15 and 20 (wt. \%) and the batch formulation of the glass samples by weight percentage (wt. \%) is listed in Table 1. Next, each glass composition was mixed homogenously for 15 minutes before it went through $1500{ }^{\circ} \mathrm{C}$ melting in an electrical furnace for 4 hours. The molten glass went through a thermal shock process from a water quenching technique during the temperature of $1500{ }^{\circ} \mathrm{C}$ to produce glass frits. Then, the dried frits were crushed and then sieved, forming a fine glass powder. For the pelleting process, 1 gram of glass powder with a drop of polyvinyl alcohol (PVA) were blended together before being pressed using a $50 \mathrm{kPa}$ hydraulic pressure and pressed to form a pellet. Lastly, the pellets were heat treated at $600,800,1000$ and $1200{ }^{\circ} \mathrm{C}$ for 3 hours.

Table 1. The batch formulation of the glass samples by weight percentage (wt. \%).

\begin{tabular}{cccccc}
\hline Samples & CS & SLS & $\mathrm{P}_{2} \mathrm{O}_{5}$ & $\mathrm{Al}_{2} \mathrm{O}_{3}$ & $\mathrm{CaF}_{2}$ \\
\hline GC1 & 15 & 40 & 20 & 20 & 5 \\
GC2 & 15 & 35 & 20 & 20 & 10 \\
GC3 & 15 & 30 & 20 & 20 & 15 \\
GC4 & 15 & 25 & 20 & 20 & 20 \\
\hline
\end{tabular}

\section{Raw materials characterisation}

An X-ray Fluorescence (XRF) was operated to identify the chemical analysis material and the composition of the CS and SLS glass. For this aim, raw CS, calcined CS and also SLS glass were crushed into a powder before being characterised by a Shimadzu Energy Dispersive X-ray Fluorescence (EDX-720) Spectrometer.

\section{Thermal properties characterisation}

The thermal parameter was analysed from a Differential Scanning Calorimetry (DSC) test where the glass samples were sent for characterisation in powder form. A TGA/DSC 1 HT machine from Mettler Toledo was operated in a temperature interval of $25^{\circ} \mathrm{C}$ until $1600{ }^{\circ} \mathrm{C}$ and a heating rate of $10^{\circ} \mathrm{C} \cdot \mathrm{min}^{-1}$. Based on the DSC result, the glass transition temperature $\left(T_{g}\right)$ and crystallisation temperature $\left(T_{c}\right)$ were determined.

\section{Physical properties characterisation}

The density was evaluated based on Archimedes' principle at room temperature. The samples in a pellet form were weighed before being immersed into distilled water with a density of $1.0 \mathrm{~g} \cdot \mathrm{cm}^{-3}$. After that, the weights of each pellet were taken and the resulting density with unit grams per cubic centimetre $\left(\mathrm{g} \cdot \mathrm{cm}^{-3}\right)$ were calculated based on the formula:

$$
\rho=\frac{W_{a}}{W_{a}-W_{b}} \rho_{b}
$$

where $W_{a}$ is weight in the air, $W_{b}$ is weight in the distilled water and $\rho_{b}$ is density of the distilled water $=1.0 \mathrm{~g} \cdot \mathrm{cm}^{-3}$.

The shrinkage percentage was evaluated by taking the diameter of the samples before and after the heat treatment process. Then, the linear shrinkage percentage for every sample was calculated based on the formula:

$$
\text { Linear shrinkage percentage }=\frac{D_{f}-D_{i}}{D_{i}} \times 100 \%
$$

where $D_{i}$ is the diameter of the pellet before the heat treatment and $D_{f}$ is the diameter of the pellet after the heat treatment. 
Structural properties characterisation

The structural properties of the samples were determined by analysing the phase formed after the heat treatment for the different temperatures. The samples in a form of powder were sent for X-ray diffraction (XRD) by using Philips PW 3040/60 X-ray Diffraction XRD Analyser with $\mathrm{Cu} \mathrm{K}$ radiation equipped with a $40 \mathrm{kV}$ accelerating voltage and a $30 \mathrm{~mA}$ input current. The range of the $2 \theta$ value is between $20^{\circ}$ to $80^{\circ}$ and the outcome was then extracted by using the $\mathrm{X}^{\prime}$ Pert Highscore software.

Next, the chemical bonding of the samples after the heat treatment were tested by using Fourier Transform Infrared Spectroscopy (FTIR) from Perkin Elmer (Model: Spectrum100 series) with a wavenumber in a range of $280 \mathrm{~cm}^{-1}$ to $1800 \mathrm{~cm}^{-1}$. The resolution used in obtaining the spectra was $4 \mathrm{~cm}^{-1}$.

The Field Emission Scanning Electron Microscopy (FESEM) characterisation was performed to observe the samples morphology by using machine from NOVA (Model: NANOSEM 230) FEI. In this characterisa-tion, the samples were sputter-coated with gold coating before being tested by using magnification of $20000 \times, 40000 \times$ and $80000 \times$.

\section{RESULTS AND DISCUSSION}

Raw materials characterisation

Table 2 depicts the chemical composition of the raw materials used to fabricate the glass composition. Based on the table, $\mathrm{Ca}$ was the main element that consisted in the CS powder with 97.70 wt. \% before the calcination (attributed from $\mathrm{CaCO}_{3}$ ) and $99.51 \mathrm{wt}$. \% after the calcination (attributed from $\mathrm{CaO}$ ). $\mathrm{Sc}_{2} \mathrm{O}_{3}, \mathrm{SO}_{3}, \mathrm{~K}_{2} \mathrm{O}$, $\mathrm{Sr}_{2} \mathrm{O}_{3}, \mathrm{ZnO}$ and $\mathrm{CuO}$ were detected in small amounts before the CS was calcined. However, $\mathrm{Sc}_{2} \mathrm{O}_{3}, \mathrm{SO}_{3}, \mathrm{~K}_{2} \mathrm{O}$, $\mathrm{Sr}_{2} \mathrm{O}_{3}$ and $\mathrm{ZnO}$ disappeared after the calcination process while $\mathrm{CuO}$ still existed in the $\mathrm{CS}$ powder.

On the other hand, elements such as $\mathrm{SiO}_{2}, \mathrm{CaO}$ and others contributed to the commercial SLS glass used in this study. $\mathrm{SiO}_{2}$ was the main compound with 56.36 wt. \% followed by $\mathrm{CaO}$ with 37.85 wt. \%. The existence of small amounts of $\mathrm{Sc}_{2} \mathrm{O}_{3}, \mathrm{SO}_{3}, \mathrm{Fe}_{2} \mathrm{O}_{3}, \mathrm{~K}_{2} \mathrm{O}$, $\mathrm{ZrO}_{2}, \mathrm{Sr}_{2} \mathrm{O}_{3}, \mathrm{ZnO}$ and $\mathrm{CuO}$ were also detected as trace elements in the commercial SLS glass. Based on the results obtained, there was a slight difference in the weight composition of the elements in the CS powder before and after the calcination. Galvan-Ruiz et al. (2009) stated that calcination process caused around $44 \%$ loss of $\mathrm{CaCO}_{3}$ from its original weight $[24,25]$. The release of $\mathrm{CO}_{2}$ gas from the $\mathrm{CS}$ powder after being calcined at $900{ }^{\circ} \mathrm{C}$ can be explained through the conversion of $\mathrm{CaCO}_{3}$ to $\mathrm{CaO}$ by the thermal decomposition process. According to previous research, the calcination process required a high temperature condition at about $700{ }^{\circ} \mathrm{C}$ to $900{ }^{\circ} \mathrm{C}$ in order to cause the complete transformation from $\mathrm{CaCO}_{3}$ to $\mathrm{CaO}$ [26-28]. The decomposition of calcite is represented by Equation 3:

$$
\mathrm{CaCO}_{3}(\mathrm{~s}) \rightarrow \mathrm{CaO}(\mathrm{s})+\mathrm{CO}_{2}(\mathrm{~g})
$$

From the table, Ca was the main element composed in the CS powder, before and after the calcination. In pioneering the glass ceramic materials for a dental application, $\mathrm{Ca}$ and $\mathrm{P}$ are significant components, since both of the elements are part of the natural composition of a tooth's structure. $\mathrm{CaO}$, which was detected in the $\mathrm{CS}$ and also SLS glass, is believed to enhance the strength of the composition apart from being a component of bones and teeth. On the other hand, $\mathrm{SiO}_{2}$, which was the major element contained in SLS glass, is responsible for the formation of the glass since it enhanced the network connectivity in an oxide form [29, 30]. Besides, the least amount of trace elements in the raw materials also contributes to the composition.

Table 2. The chemical composition for the raw CS, calcined CS and SLS glass.

\begin{tabular}{lccc}
\hline \multirow{2}{*}{ Compound } & \multicolumn{3}{c}{ Weight composition (wt. \%) } \\
\cline { 2 - 4 } & Raw CS & Calcined CS & SLS glass \\
\hline $\mathrm{SiO}_{2}$ & - & - & 56.36 \\
$\mathrm{CaCO}_{3}$ & 97.70 & - & - \\
$\mathrm{CaO}$ & - & 99.51 & 37.85 \\
$\mathrm{Sc}_{2} \mathrm{O}_{3}$ & 0.35 & - & 2.84 \\
$\mathrm{SO}_{3}$ & 0.31 & - & 1.11 \\
$\mathrm{Fe}_{2} \mathrm{O}_{3}$ & - & 0.04 & 0.87 \\
$\mathrm{~K}_{2} \mathrm{O}$ & 0.47 & - & 0.62 \\
$\mathrm{ZrO}_{2}$ & - & - & 0.11 \\
$\mathrm{Sr}_{2} \mathrm{O}_{3}$ & 0.27 & - & 0.09 \\
$\mathrm{ZnO}_{\mathrm{SrO}}$ & 0.66 & - & 0.07 \\
$\mathrm{CuO}$ & - & 0.35 & 0.04 \\
$\mathrm{Ho}$ & 0.24 & 0.03 & 0.04 \\
\hline
\end{tabular}

\section{Thermal properties characterisation}

The DSC results for the GC1, GC2, GC3 and GC4 samples are shown in Table 3 . The table reveal the $T_{g}$ and $T_{c}$ of the samples, which were between $520-580{ }^{\circ} \mathrm{C}$ and $850-950{ }^{\circ} \mathrm{C}$, respectively. It was observed that sample with lowest $\mathrm{CaF}_{2}$ content resulted in the highest $T_{g}$ and $T_{c}$ values compared to the sample with the highest $\mathrm{CaF}_{2}$ content. Both the $T_{g}$ and $T_{c}$ decreased as the $\mathrm{CaF}_{2}$ content increased and this result is supported by previous research studies [6, 14, 31-33]. $\mathrm{CaF}_{2}$ works as a network disrupter by means of the $\mathrm{CaF}_{2}$ addition into the glass composition reduced the Coulomb interaction between the non-bridging oxygen in order to form the nonbridging fluorine. In this case, the substitution of $\mathrm{CaF}^{+}$ to the silicate ions consequently lowered the $T_{g}[34,35]$. At the same moment, the density of glass chains was lessened by the presence of $\mathrm{CaF}_{2}$, thus it advanced the 
particle movement and also the rearrangement of the amorphous state to the crystalline state [36, 37]. As a consequence, the crystallisation of the samples occurred. Therefore, the $T_{c}$ values decrease as the amount of $\mathrm{CaF}_{2}$ added into the glass composition increases.

Table 3. The thermal parameter of the glass ceramic samples.

\begin{tabular}{ccc}
\hline Samples & $T_{g}\left({ }^{\circ} \mathrm{C}\right)$ & $T_{c}\left({ }^{\circ} \mathrm{C}\right)$ \\
\hline GC1 & 580 & 950 \\
GC2 & 550 & 900 \\
GC3 & 540 & 880 \\
GC4 & 520 & 850 \\
\hline
\end{tabular}

Physical properties characterisation

Figure 1 shows the density of the glass and glass ceramic samples with the different heat treatment temperatures. The density results of the glass samples were recorded at $27{ }^{\circ} \mathrm{C}$ (without the heat treatment) and the results showed an increment in the density as the amount of $\mathrm{CaF}_{2}$ increased except for the $\mathrm{GC} 2$ sample. When compared to the samples which went through the heat treatment, the density values were higher for the treated samples. This is due to the crystal formation in the samples. By referring to the figure, all the samples showed an increase in density within the heat treatment temperature, and the highest density for the different $\mathrm{CaF}_{2}$ content glass ceramic samples was observed at $1000{ }^{\circ} \mathrm{C}$. At $1000{ }^{\circ} \mathrm{C}$, the highest density was recorded in the GC4 sample which contained a high amount of $\mathrm{CaF}_{2}$ with a density of $2.787 \mathrm{~g} \cdot \mathrm{cm}^{-3}$. For comparison, the $\mathrm{GC} 1$ sample with a low amount of $\mathrm{CaF}_{2}$ had a density of $2.623 \mathrm{~g} \cdot \mathrm{cm}^{-3}$, which was the lowest density obtained among the four glass ceramic samples at the same heat treatment temperatures. However, the density trend showed a decrease when the samples were treated at $1200{ }^{\circ} \mathrm{C}$. Among all the glass ceramic samples, the GC3 and GC4 samples showed a higher density when

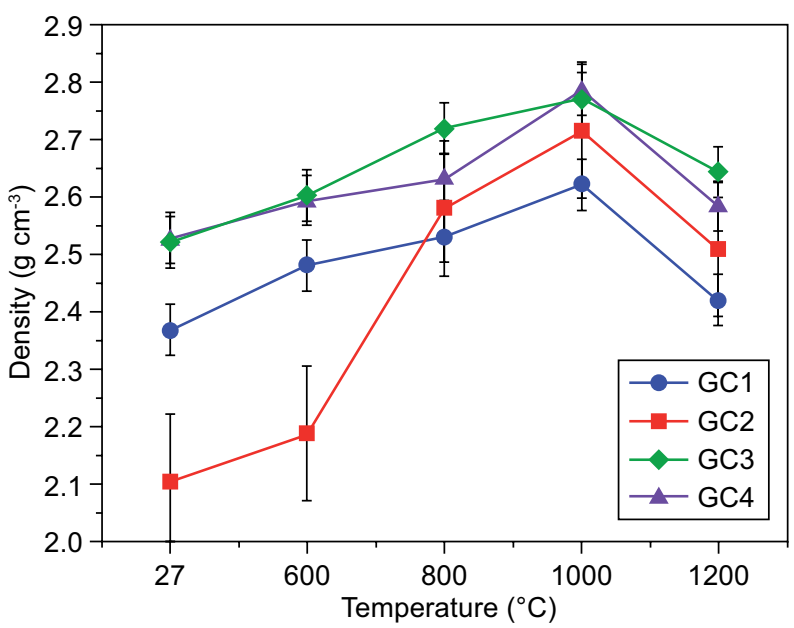

Figure 1 . The density of the glass and glass ceramic samples with the different heat treatment temperatures. compared to the GC1 and GC2 samples. Thus, the higher the amount of $\mathrm{CaF}_{2}$ in the sample, the higher the density obtained from the sample.

A sudden decrease in density occurred in the glass sample as well as the lower heat treatment temperature of the GC2 sample, this might be due to the agglomeration of the powder that occurred during the sample preparation. A study from Ciftcioglu (1987) reported that the adsorbed moisture and the type of binders used in the preparation of the samples resulted in a weak agglomeration which might disturb the nature of the bonds and, thus, affect the physical properties of the samples such as the density, strength, particle size as well as the packing density of the resulting samples [38]. However, the density of the GC2 sample increased dramatically when the sample went through the heat treatment at $800{ }^{\circ} \mathrm{C}$ and above. The higher temperature of the heat treatment caused the elimination of the moisture in the samples which then affected the particle kinetics, thus contributing to a sudden increase in the density [39].

As shown in Figure 1, the sample density decreased as the temperature of the heat treatment rose until the maximum temperature of $1000{ }^{\circ} \mathrm{C}$ was achieved. The same outcome was revealed by previous studies which explained that the decrease in the density measurement of the samples after they reached their optimal temperature was due to the increasing of the lattice parameter and the volume of the samples [40]. The heat treatment process supplied energy to the particles in the sample, which caused the atom to vibrate and rearrange from a random ordered, amorphous phase of the glass to a properly ordered, crystalline phase of glass ceramics. The density increased as the atoms packed together [20] until they achieved an optimum heat treatment temperature. However, after the sample passed its optimal temperature, the density started to decrease since there is porosity produced in the sample because of the $\mathrm{CO}_{2}$ gas being eliminated during the calcite decomposition especially when subjected to a higher heat treatment temperature $[21,41]$. Besides, the density of the samples is also affected by the different amounts of $\mathrm{CaF}_{2}$ added into the ASF composition. Figure 1 revealed that a higher amount of $\mathrm{CaF}_{2}$ added to the composition produced a greater density of the glass ceramic samples. In this case, $\mathrm{CaF}_{2}$ behaves as a facilitator in the crystallisation process where the viscosity [42] is being lowered by reducing the resistance of the flow due to the broken electrostatic bindings in the glass composition.

The results of the linear shrinkage percentage for all the glass ceramic samples are presented in Figure 2. As observed in Figure 2, the highest linear shrinkage was observed in the GC2 sample during the heat treatment temperature of $1000{ }^{\circ} \mathrm{C}$ with $13.804 \%$. The same results were also obtained by other glass ceramic samples, where they showed the highest linear shrinkage percentage during the $1000{ }^{\circ} \mathrm{C}$ heat treatment process, except for the GC3 sample, which showed the highest linear shrinkage 
percentage during the $1200{ }^{\circ} \mathrm{C}$ heat treatment process. Next, during the $1200{ }^{\circ} \mathrm{C}$ heat treatment process, the GC1, GC2 and GC4 samples had a little decrease in the linear shrinkage percentage which was almost similar to the density trend. The different $\mathrm{CaF}_{2}$ content produced a different linear shrinkage, where it was observed that the GC1 and GC2 samples produced a greater linear shrinkage when compared to the GC3 and GC4 samples.

The linear shrinkage percentage increased as the temperature for the heat treatment increased. With the aid of the heat treatment method, the realignment of the particles in the arranged shape resulted in a decrease in the percentage shrinkage of the glass ceramic sample. However, the linear shrinkage percentage of the GC1, GC2 and GC4 samples decreased when subjected to the $1200{ }^{\circ} \mathrm{C}$ heat treatment process. This corresponds to the density analysis at $1200{ }^{\circ} \mathrm{C}$, which revealed the decomposition of a large amount of calcite, thus $\mathrm{CO}_{2}$ gas trapped in the sample was released. Besides, the linear shrinkage percentage also showed a decrease due to the high amount of $\mathrm{CaF}_{2} \cdot \mathrm{CaF}_{2}$ acts as a nucleation agent where it improves the crystallisation formation, thus increasing the crystallite size. When the crystallite size of the sample increased, its volume also increased and, as a consequence, the linear shrinkage of the sample decreased. Wilson et al., (1980) noticed that the $\mathrm{CaF}_{2}$ content increased the nucleation and glass ceramic's growth [43] while Riaz et al., (2017) also agreed that the $\mathrm{CaF}_{2}$ addition improved the crystallite size [44], thus resulting in a larger size of the sample, hence reducing the linear shrinkage.

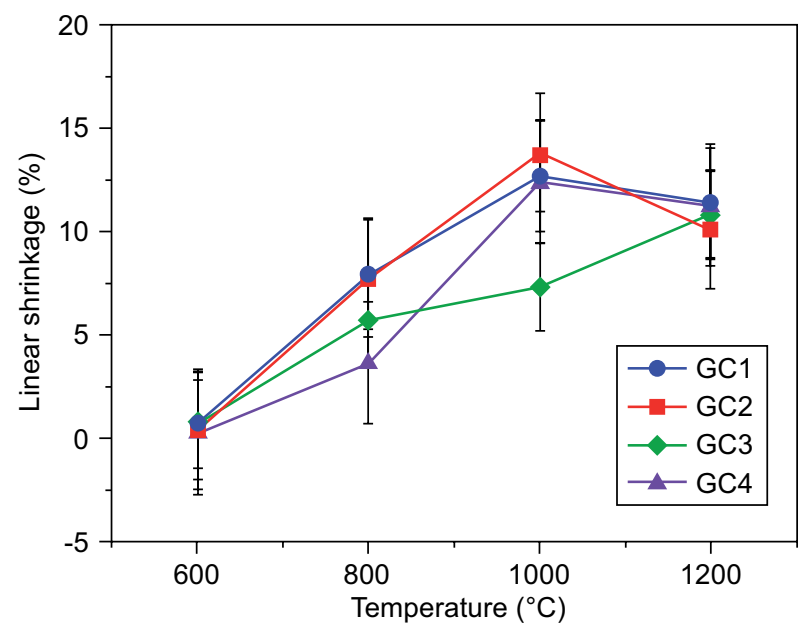

Figure 2. The linear shrinkage percentage of the glass ceramic samples with the different heat treatment temperatures.

\section{Structural properties characterisation}

Figure 3 shows the XRD graphs of the glass ceramic samples with the different heat treatment temperatures while Table 4 depicts the summary of the phases present in the glass ceramic samples. The crystalline phase of fluorapatite $\left(\mathrm{Ca}_{5}\left(\mathrm{PO}_{4}\right)_{3} \mathrm{~F}\right.$, NO JPDS: 98-001-7206) was the main phase that existed at the $600{ }^{\circ} \mathrm{C}$ heat treatment temperature and becomes optimum with the increasing amount of $\mathrm{CaF}_{2}$. Next, the growth of mullite $\left(\mathrm{Al}_{5} \mathrm{SiO}_{9.5}\right.$, NO JPDS: 98-002-3557) happens in all the samples when they went through the heat treatment process at $1000{ }^{\circ} \mathrm{C}$ while anorthite, $\left(\mathrm{Ca}\left(\mathrm{Al}_{2} \mathrm{Si}_{2} \mathrm{O}_{8}\right)\right.$, NO JPDS: 98-000-6200) grew when heat treatment started at $1000{ }^{\circ} \mathrm{C}$ in the $\mathrm{GC} 1$ and $\mathrm{GC} 3$ samples. At the $1200{ }^{\circ} \mathrm{C}$ heat treatment process, all the crystalline phases existed in all the samples except for the GC4 sample.

Based on Figure 3, the higher heat treatment temperature promoted the optimum growth of the crystalline phases and the higher diffraction peaks intensity of fluorapatite also. This is due to the role of the heat treatment in fastening the atomic mobility, thus leading to grain growth and resulting in the better crystallinity of the glass ceramic sample [45]. In addition, the involvement of $\mathrm{CaF}_{2}$ in the apatite-mullite glass ceramics system as a nucleating agent and also as a facilitator in the crystallisation process encouraged the growth of crystal phases in the samples [8]. Besides, the crystallisation of fluorapatite and mullite from the $600{ }^{\circ} \mathrm{C}$ until $1000{ }^{\circ} \mathrm{C}$ heat treatment process showed that the high $\mathrm{CaF}_{2}$ content caused the formation of the fluorapatite and mullite phases while the anorthite phase crystallised at higher temperatures. However, the crystal phase formation relied on the composition stoichiometry and heat treatment behaviour [46, 47]. Some researchers had found that the $\mathrm{Ca} / \mathrm{P}$ ratio and fluorine addition in the glass composition determines the crystallisation of the glass system [10, 46].

As observed from the XRD pattern, the apatite phase was formed during the early stage of the heat treatment due to composition of the calcium phosphate-rich droplet phase subsequent to the amorphous phase separation [9]. According to Bogdanov et al. (2008), fluorapatite is a type of calcium phosphate group where the $\mathrm{OH}^{-}$are substituted by $\mathrm{F}^{-}$ions [48]. Fluorapatite is much more stable than hydroxyapatite in an acidic environment and very beneficial in dentistry. Besides, it served as the nuclei for the crystal growth [3] with the help of the heat treatment process. The formation of the mullite phase was attributed from the removal of the calcium and phosphate ion from the network of the fluorapatite phase, which increased the aluminium to silicon, plus the phosphate ratio above one, thus resulting in insufficient $\mathrm{Ca}^{2+}$ and $\mathrm{P}^{5+}$ ions being available to balance the charge deficient $\mathrm{Al}^{3+}$ ion in a four coordinate system [10]. This situation forced the aluminium into a higher five and six coordination environment, thus favouring the formation of mullite where aluminium was within the mixture of the four- and six-coordinate states [49]. In other words, the evacuation of the glass network when the crystallisation of fluorapatite started in F, Ca, and $\mathrm{P}$ that caused a homogenous reaction to occur which then formed the mullite phase [9]. 
Based on the XRD graph, the productive growth of the anorthite phase was observed in the GC3 and GC4 samples which were produced from high heat treatment temperature and higher $\mathrm{CaF}_{2}$ content. The growth of anorthite, when the samples were heat treated at

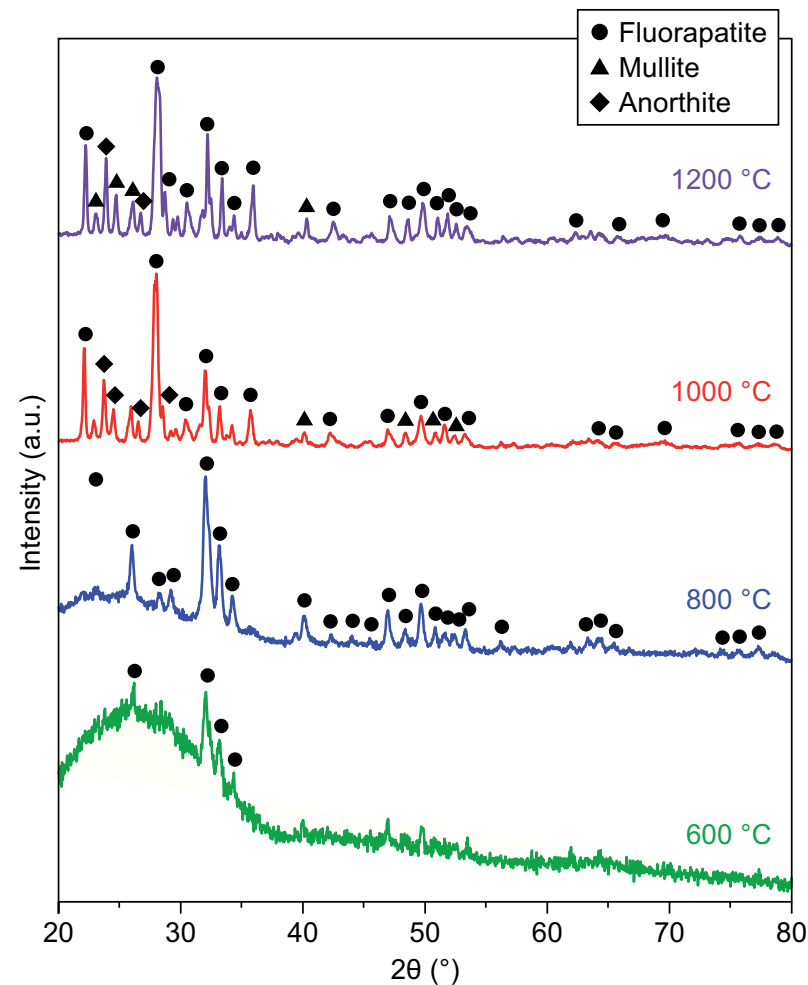

a) $\mathrm{GC} 1$

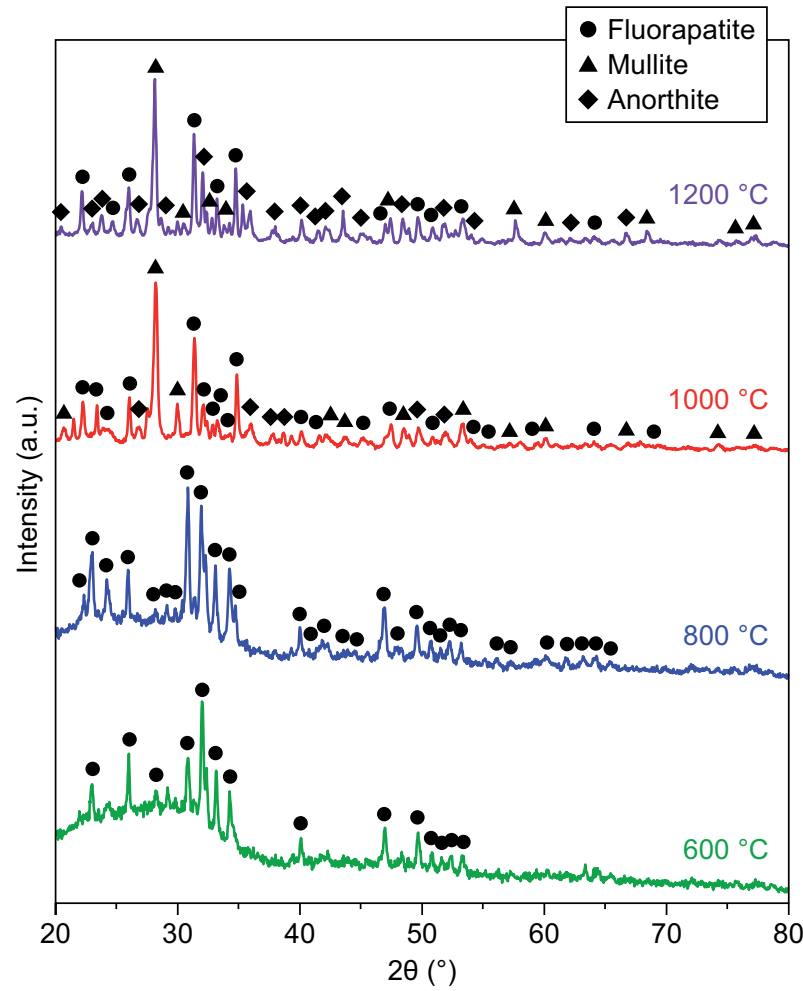

c) $\mathrm{GC} 3$ higher temperature, was supported by the results from Samuneva et al. (1998) as they found that anorthite and gehlenite phase grew at higher temperatures while fluorapatite and mullite formed at lower heat treatment temperatures [7]. However, the dominant growth of

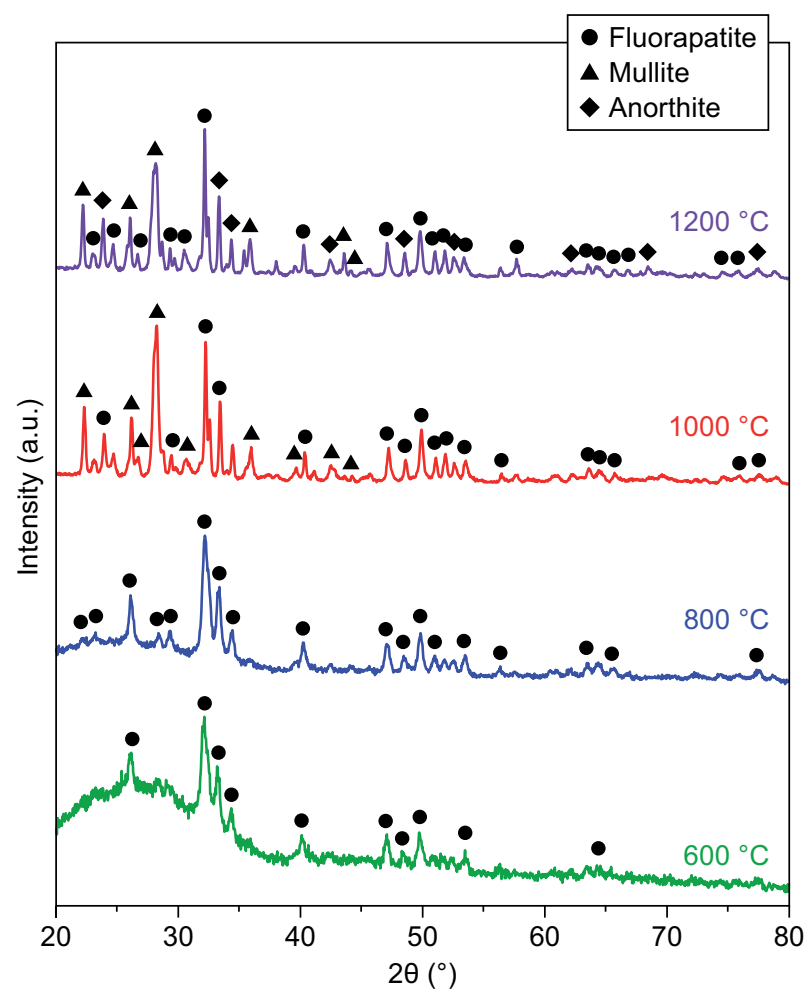

b) $\mathrm{GC} 2$

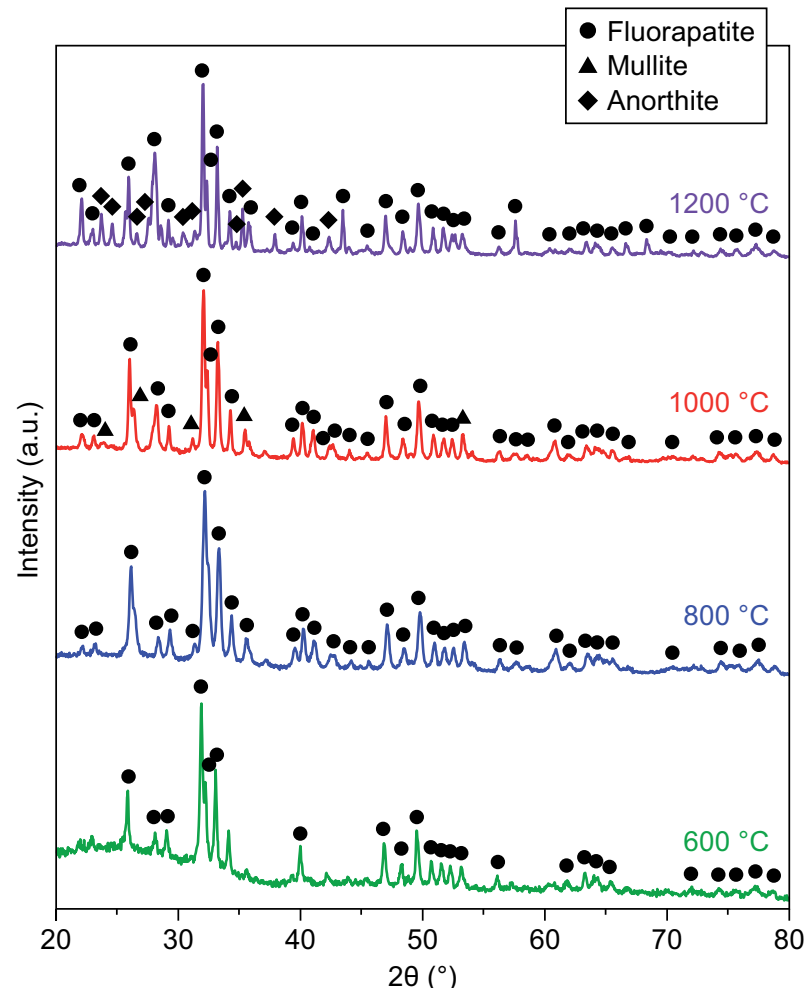

d) $\mathrm{GC} 4$

Figure 3. The XRD results for: a) GC1, b) GC2, c) GC3, and d) GC4, heat treated at $600{ }^{\circ} \mathrm{C}, 800{ }^{\circ} \mathrm{C}, 1000{ }^{\circ} \mathrm{C}$ and $1200^{\circ} \mathrm{C}$. 
the anorthite phase in the samples with the higher $\mathrm{CaF}_{2}$ content was detected and this result was opposite with studies from Samuneva et al. (1998) and also Stanton and Hill (2005), where they found that the anorthite phase became dominant in a low fluorine content composition $[7,9]$. When the amount of fluorine added was reduced, the crosslink density increased, thus inhibiting the glass phase separation which then formed the energy barrier for the bulk nucleation of fluorapatite to occur. Therefore, anorthite was formed in the glass composition with a residual glass phase rich with calcium in order to maintain the four coordinate state of aluminium [10].

Table 4. The phases present in the samples for the different $\mathrm{CaF}_{2}$ compositions and heat treatment temperatures.

\begin{tabular}{|c|c|c|c|c|}
\hline Samples & $\mathrm{GC} 1$ & $\mathrm{GC} 2$ & GC3 & GC4 \\
\hline $600^{\circ} \mathrm{C}$ & Fluorapatite & Fluorapatite & Fluorapatite & Fluorapatite \\
\hline $800^{\circ} \mathrm{C}$ & Fluorapatite & Fluorapatite & Fluorapatite & Fluorapatite \\
\hline $1000^{\circ} \mathrm{C}$ & $\begin{array}{c}\text { Fluorapatite } \\
\text { Mullite } \\
\text { Anorthite }\end{array}$ & $\begin{array}{c}\text { Fluorapatite } \\
\text { Mullite } \\
-\end{array}$ & $\begin{array}{c}\text { Fluorapatite } \\
\text { Mullite } \\
\text { Anorthite }\end{array}$ & $\begin{array}{c}\text { Fluorapatite } \\
\text { Mullite } \\
-\end{array}$ \\
\hline $1200^{\circ} \mathrm{C}$ & $\begin{array}{c}\text { Fluorapatite } \\
\text { Mullite } \\
\text { Anorthite }\end{array}$ & $\begin{array}{c}\text { Fluorapatite } \\
\text { Mullite } \\
\text { Anorthite }\end{array}$ & $\begin{array}{c}\text { Fluorapatite } \\
\text { Mullite } \\
\text { Anorthite }\end{array}$ & $\begin{array}{c}\text { Fluorapatite } \\
\text { Anorthite }\end{array}$ \\
\hline
\end{tabular}

The FTIR results of the glass ceramic samples are shown in Figure 4 and the spectral band assigned to the vibrational modes is revealed in Table 5. Based on Figure 4, the $\mathrm{Si}-\mathrm{O}-\mathrm{Si}$ tetrahedral in the range of $\sim 800-1250 \mathrm{~cm}^{-1}$ and the $\mathrm{C}-\mathrm{O}$ stretching in the range of $\sim 1400-1500 \mathrm{~cm}^{-1}$ existed in all the glass ceramic samples. The $\mathrm{Si}-\mathrm{O}-\mathrm{Si}$ bending mode was observed in certain samples, especially when treated for $600{ }^{\circ} \mathrm{C}$ and $800{ }^{\circ} \mathrm{C}$ at wavenumber $\sim 415-540 \mathrm{~cm}^{-1}$. Besides, the existence of the phosphate group represented by the $\mathrm{P}-\mathrm{O}-\mathrm{P}$ symmetric and $\mathrm{P}-\mathrm{O}$ bending modes were detected to occur during the $600{ }^{\circ} \mathrm{C}$ heat treatment process at wavenumber $\sim 720-760 \mathrm{~cm}^{-1}$ and $\sim 550-560 \mathrm{~cm}^{-1}$ respectively. Nevertheless, the P-O-P symmetric mode vanished in the GC4 sample while it can be clearly seen in the sample with the low $\mathrm{CaF}_{2}$ content. In addition, the $\mathrm{O}-\mathrm{H}$ stretching mode was discovered in the GC4 sample at wavenumber $1646 \mathrm{~cm}^{-1}$ during the heat treatment temperature of $1000{ }^{\circ} \mathrm{C}$.

Based on the FTIR results, both the bending and tetrahedral modes of $\mathrm{Si}-\mathrm{O}-\mathrm{Si}$ at wavenumber $\sim 415-540$ and $\sim 800-1250 \mathrm{~cm}^{-1}$ respectively that emerged in the samples proved existence of the Si element incorporated in the SLS glass powder $[23,50]$. The wavenumber of $930 \mathrm{~cm}^{-1}$, which was observed in all the glass ceramic samples, belonged to the $\mathrm{Si}-\mathrm{O}^{-}$stretching vibration with a non-bridging oxygen [3]. A very weak peak at wavenumber $\sim 1600-1650 \mathrm{~cm}^{-1}$ observed in GC4, especially when heat treated at 1000 and $1200{ }^{\circ} \mathrm{C}$, was due to the $\mathrm{O}-\mathrm{H}$ stretching mode of $\mathrm{H}_{2} \mathrm{O}$ that was absorbed by the glass ceramic sample. Besides, the presence of the $\mathrm{P}-\mathrm{O}$ bending mode at wavenumber $\sim 550-560 \mathrm{~cm}^{-1}$ and the P-O-P symmetric bond at $\sim 720-760 \mathrm{~cm}^{-1}$ proved the apatite phase development in the samples when the heat treatment started from $600{ }^{\circ} \mathrm{C}[2,51-$ 53]. In addition, an unsteady $\mathrm{C}-\mathrm{O}$ stretching mode was detected at wavenumber $\sim 1393 \mathrm{~cm}^{-1}$, which revealed the existence of the carbonate group present in the $\mathrm{CaO}$ composition [25, 54, 55].

From Figure 4, the $\mathrm{CaF}_{2}$ content may change the line width of the peak without changing the peak. In this case, the $\mathrm{CaF}_{2}$ through the glass structure acts as a network modifier that interrupted the network which belongs to the $\mathrm{Si}-\mathrm{O}-\mathrm{Si}$ mode. Other than that, the radius of the fluoride ion was close to the oxygen ion, hence it forced the bond of $\mathrm{Si}-\mathrm{O}-\mathrm{Si}$ to be replaced by two $\mathrm{Si}-\mathrm{F}$ bonds [56]. The fluorine from $\mathrm{CaF}_{2}$ was a network disrupter which acts to lessen the silica network and also increase the ion migration which then causes the glass phase separation [43]. However, based on the figure, there was an absence of the $\mathrm{CaF}_{2}$ bond in the sample which was supported by Kim et al., (1989), where the existence of fluorite was to remain undiscovered if the samples were treated by FTIR only [57].

Table 5. The assignment of the vibrational mode based on the wavenumbers.

\begin{tabular}{ccc}
\hline $\begin{array}{c}\text { Wavenumbers } \\
\left(\mathrm{cm}^{-1}\right)\end{array}$ & $\begin{array}{c}\text { Assignment of } \\
\text { vibrational mode }\end{array}$ & References \\
\hline$\sim 415-540$ & $\mathrm{Si}-\mathrm{O}-\mathrm{Si}$ bending mode & {$[56,58]$} \\
$\sim 550-560$ & $\mathrm{P}-\mathrm{O}$ bending mode & {$[51,59]$} \\
$\sim 720-760$ & $\mathrm{P}-\mathrm{O}-\mathrm{P}$ symmetric mode & {$[53]$} \\
$\sim 800-1250$ & $\mathrm{Si}-\mathrm{O}-\mathrm{Si}$ tetrahedral mode & {$[60,61]$} \\
$\sim 1400-1500$ & $\mathrm{C}-\mathrm{O}$ stretching mode & {$[25]$} \\
$\sim 1600-1650$ & $\mathrm{O}-\mathrm{H}$ stretching mode & {$[25]$} \\
\hline
\end{tabular}

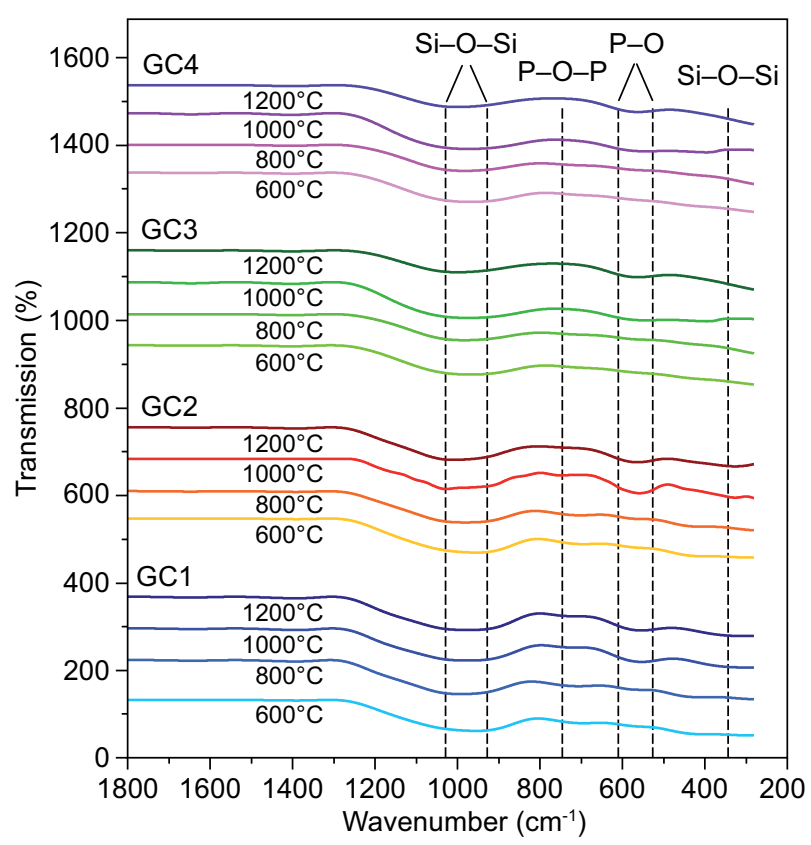

Figure 4. The FTIR results for the glass ceramic samples with the different heat treatment temperatures. 
The FESEM images in Figure 5 show the morphology of the glass ceramic samples with the different heat treatment temperatures while Figure 6 confirmed the needle-like microstructure of apatite crystal arising from the glass ceramic composition when subjected to higher magnification. Based on Figure 5, it was observed that at the early stage of heat treatment, the particles in the FESEM morphology have no regular size and shape in all the samples. The low heat treatment temperature was observed to contribute no significant particles diffusing on the glass ceramic samples. However, as the heat treatment temperature increased, the grain size of the samples increased [14, 23].

The influence of the heat treatment temperature on the glass ceramic samples was observed from the microstructure of the samples when heat treated at $800{ }^{\circ} \mathrm{C}$ and above. From the observation, the aggregation of the

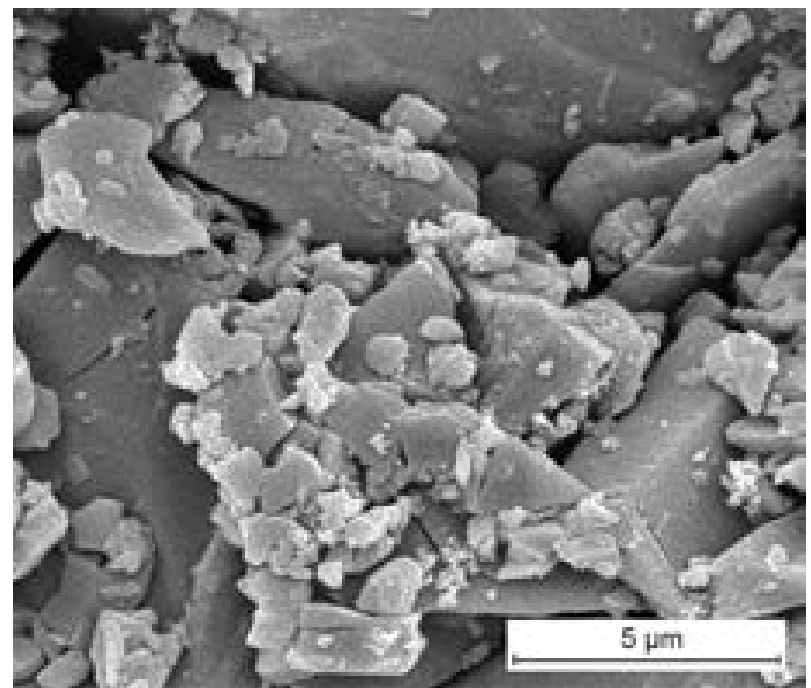

$600{ }^{\circ} \mathrm{C}$

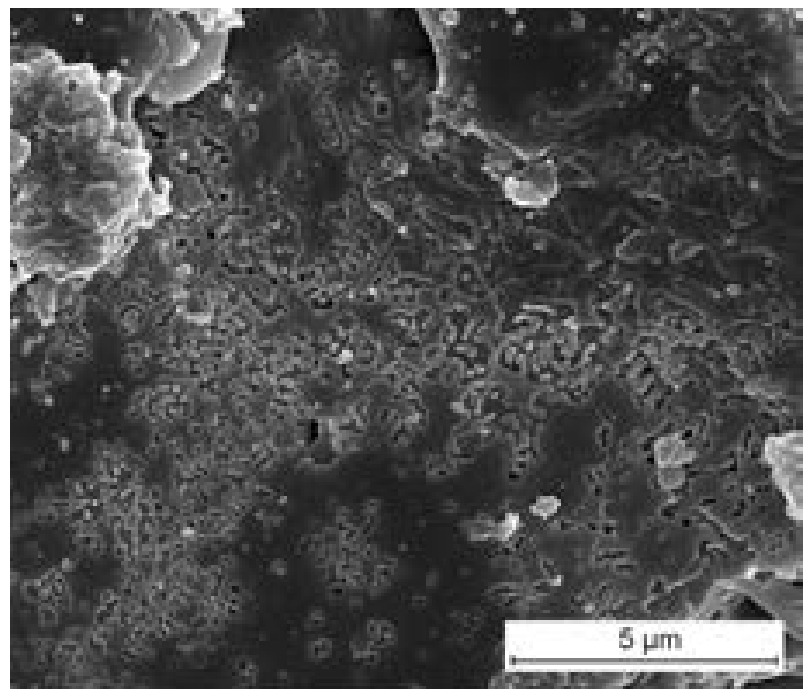

$1000^{\circ} \mathrm{C}$ particles was seen in the GC1, GC3 and GC4 samples heat treated at $800{ }^{\circ} \mathrm{C}$. However, the GC2 sample showed a different microstructure due to the agglomeration of the powder sample. Based on previous literature, the powder agglomeration affected the microstructure, strength, size and size distribution of the resulting samples $[62,63]$. When all of the glass ceramic samples went through $1000{ }^{\circ} \mathrm{C}$ and $1200{ }^{\circ} \mathrm{C}$ of heat treatment, the microstructure of the samples was seen to become granular and homogenously distributed at the surface of the samples. Therefore, the higher heat treatment temperature increased the crystal grains of the glass ceramic samples.

The appearance of the needle-like crystal structure in the glass ceramic samples at the lower heat treatment temperatures as well as higher heat treatment temperatures proved the existence of the apatite phase in the samples as explained in the XRD analysis. Besides,

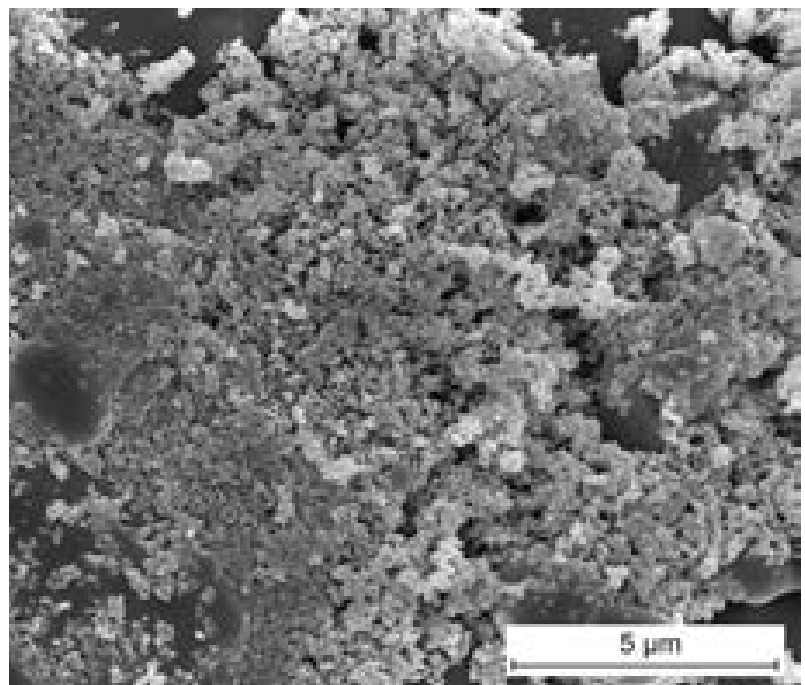

$800{ }^{\circ} \mathrm{C}$

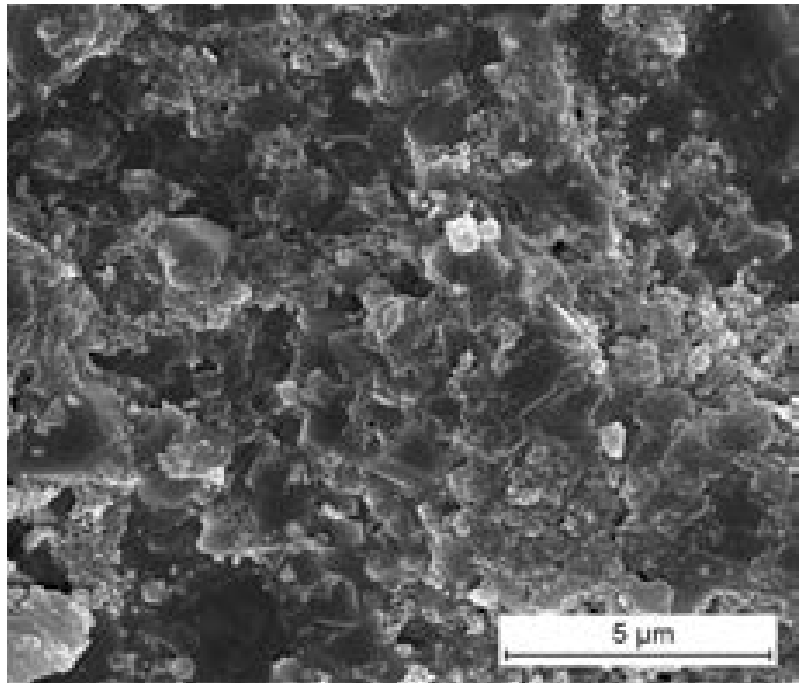

$1200{ }^{\circ} \mathrm{C}$

a) $\mathrm{GC} 1$

Figure 5. The FESEM images for the glass ceramic samples with the different heat treatment temperature. (Continue on next page) 


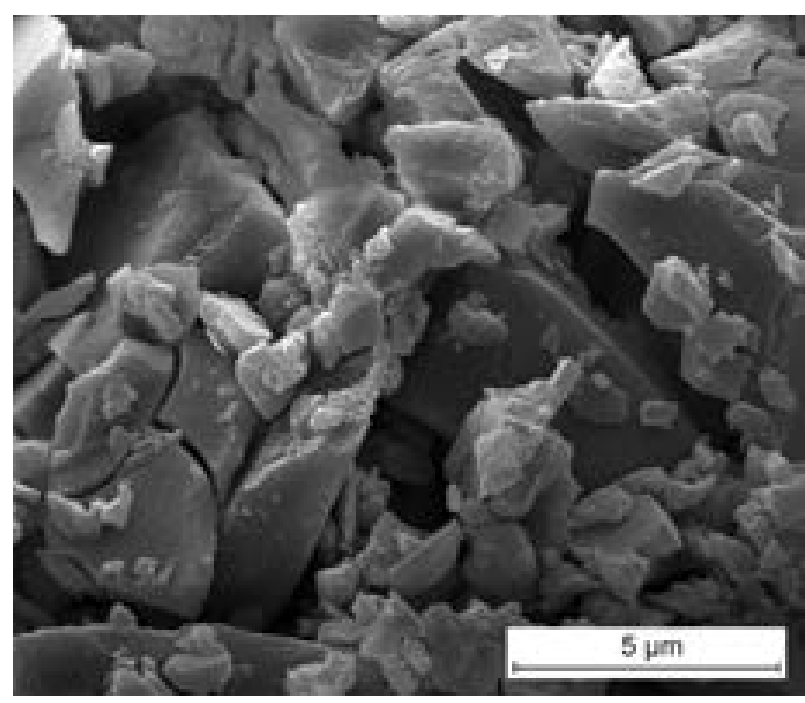

$600{ }^{\circ} \mathrm{C}$

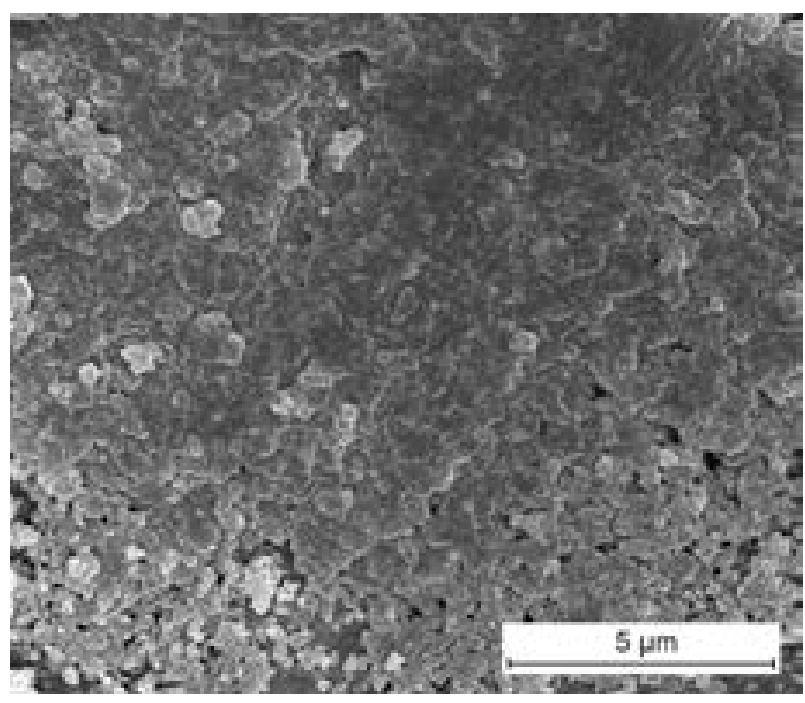

$1000^{\circ} \mathrm{C}$

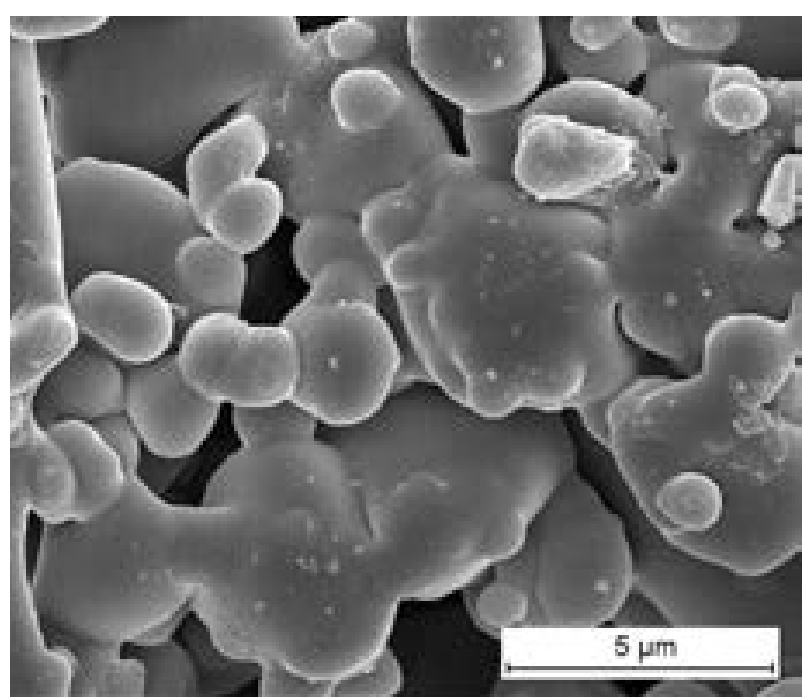

$800{ }^{\circ} \mathrm{C}$

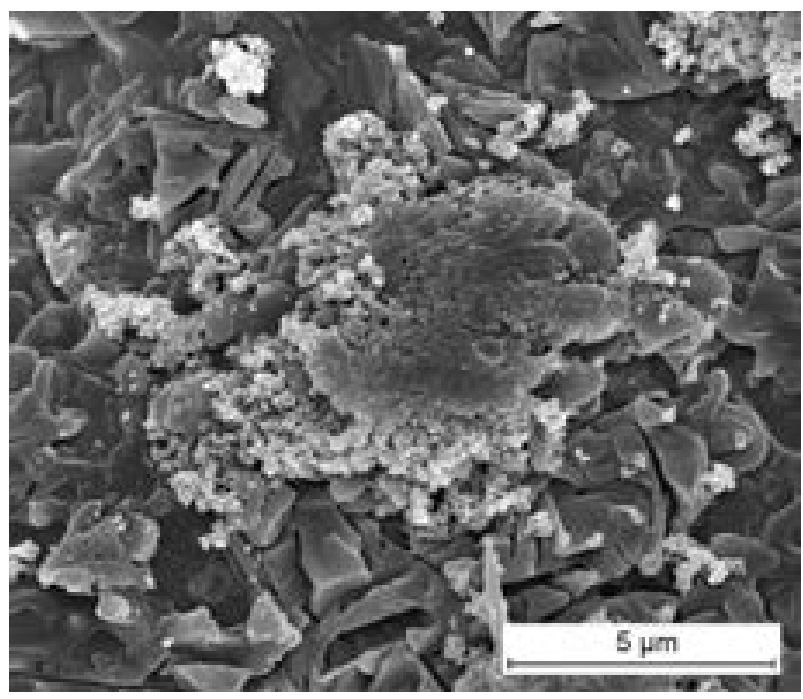

$1200^{\circ} \mathrm{C}$

b) $\mathrm{GC} 2$

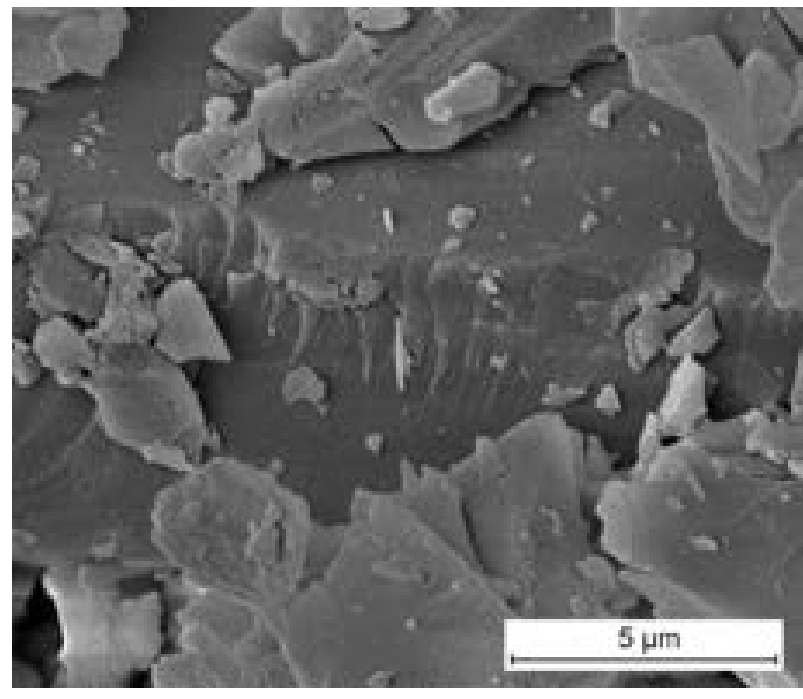

$600^{\circ} \mathrm{C}$

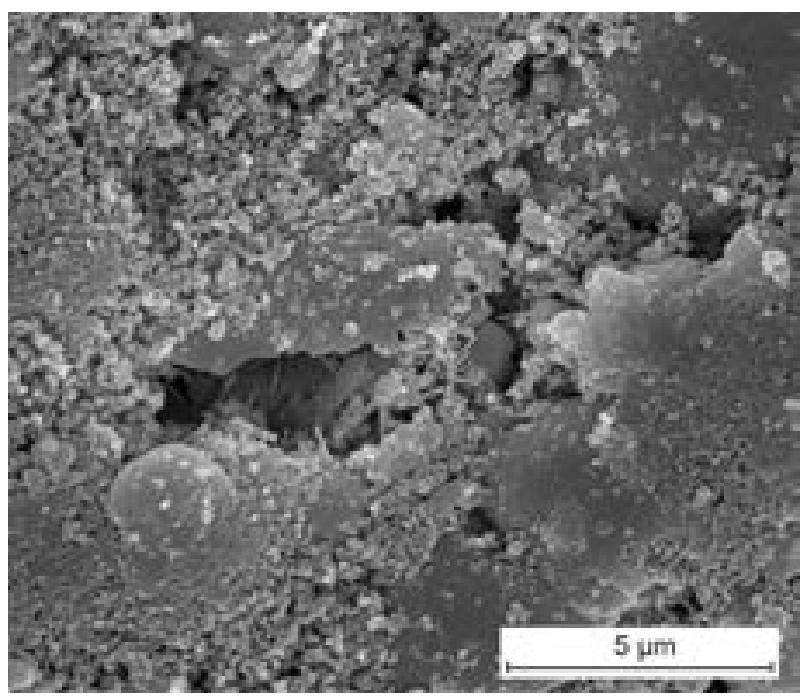

$800{ }^{\circ} \mathrm{C}$

c) $\mathrm{GC} 3$

Figure 5. The FESEM images for the glass ceramic samples with the different heat treatment temperature. (Continue on next page) 


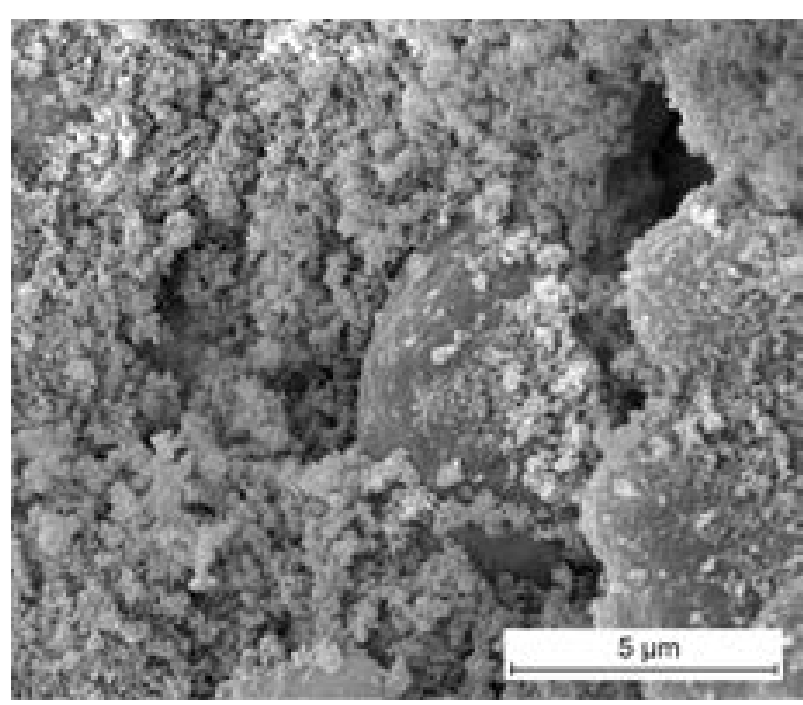

$1000{ }^{\circ} \mathrm{C}$

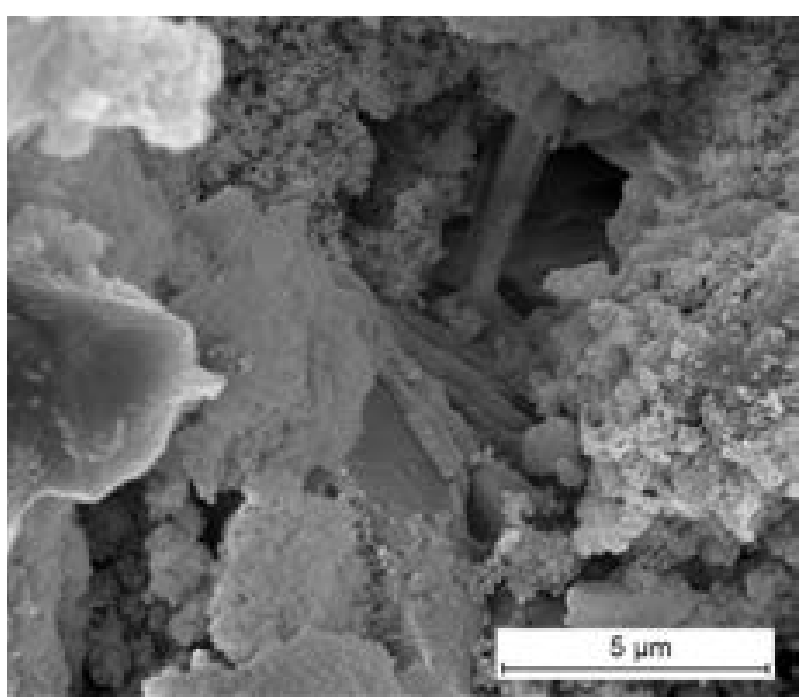

$1200^{\circ} \mathrm{C}$

c) $\mathrm{GC} 3$

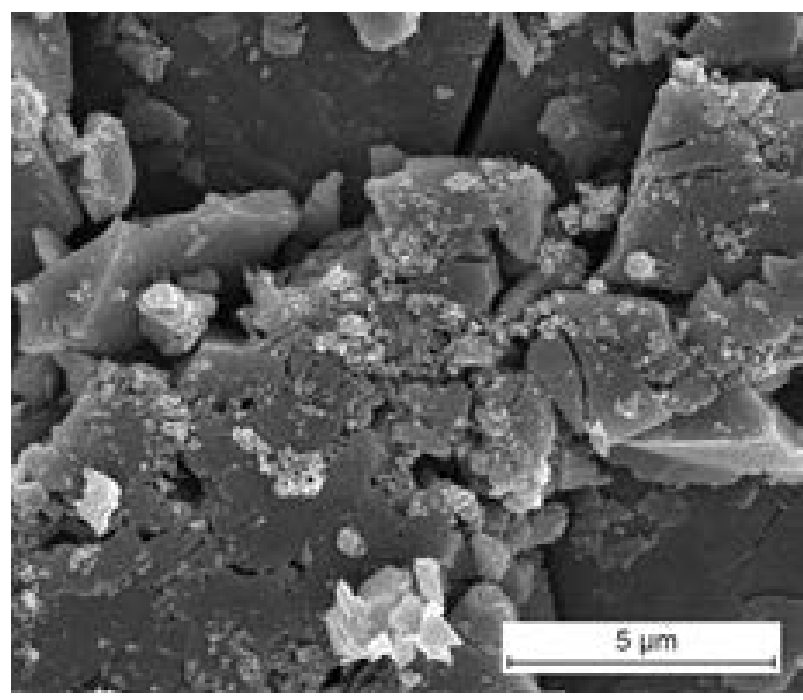

$600{ }^{\circ} \mathrm{C}$

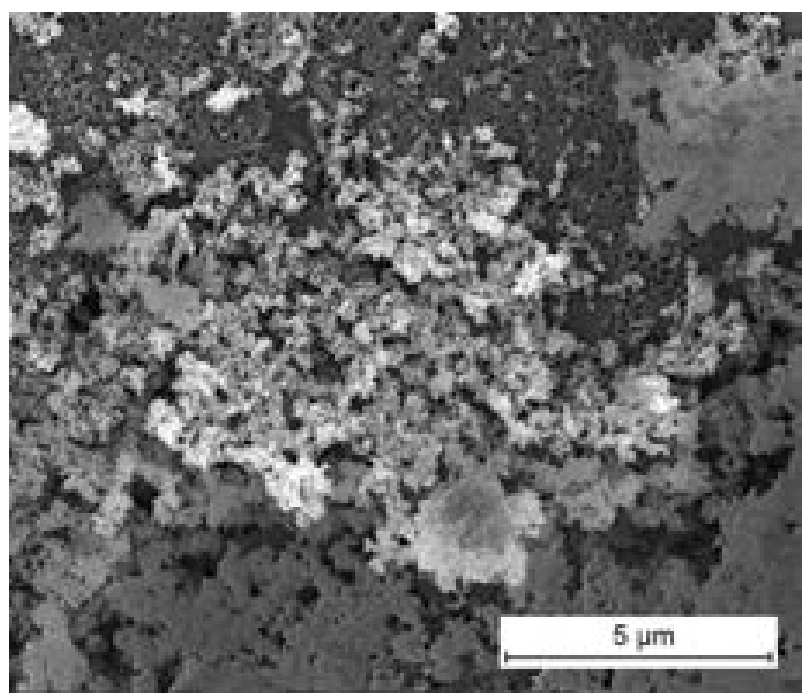

$1000^{\circ} \mathrm{C}$

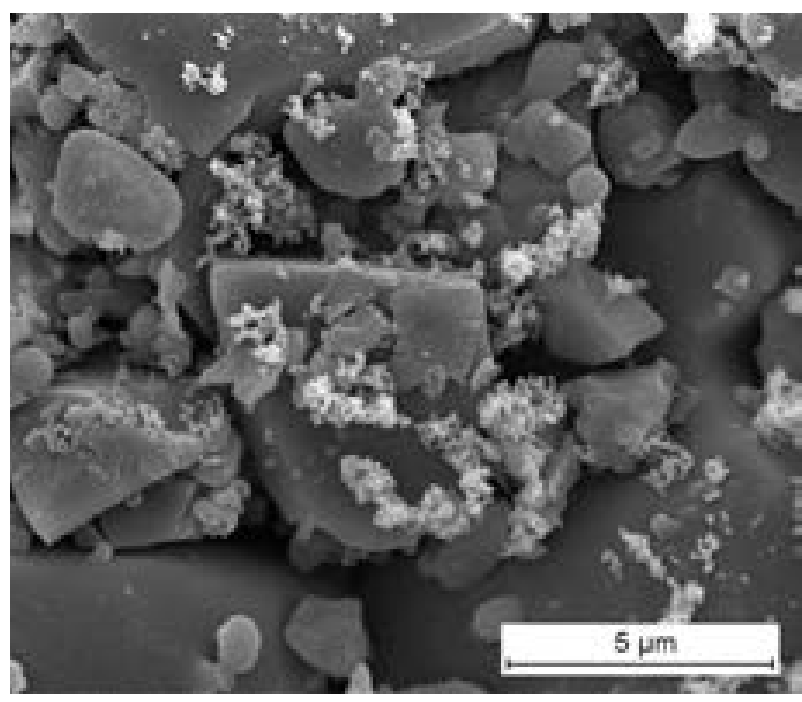

$800{ }^{\circ} \mathrm{C}$

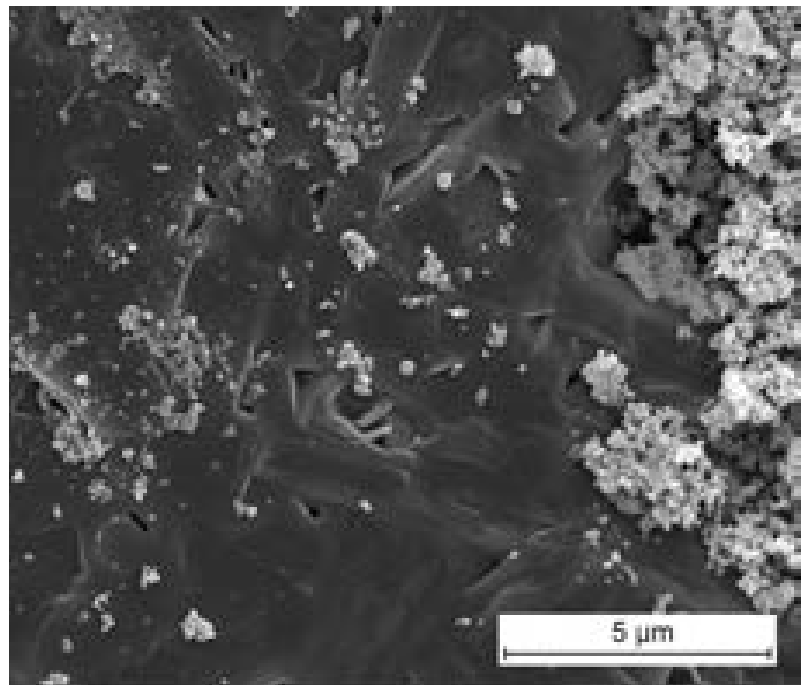

$1200{ }^{\circ} \mathrm{C}$

d) $\mathrm{GC} 4$

Figure 5. The FESEM images for the glass ceramic samples with the different heat treatment temperature. 
the geometrical grains formed when the samples went through the higher heat treatment temperature might be constructed by the orthorhombic and triclinic owned by the mullite and anorthite phase, respectively. According to Hill and Wood (1995), the heat treatment of fluoride containing glasses result in the formation of long needlelike crystals known as fluorapatite with a hexagonal structure while increasing the heat treatment temperature causes the crystallisation of mullite along with the apatite structure [33]. Increasing the heat treatment temperature causes the formation of the mullite and anorthite phase as a result of the breaking and rearrangement of the glass network, especially the $\mathrm{Si}-\mathrm{O}$ and $\mathrm{Al}-\mathrm{O}$ bonds [33].

The FESEM images from Figures 5 and 6 proved the crucial role of $\mathrm{CaF}_{2}$ in the crystallisation of the glass ceramic samples. A high $\mathrm{CaF}_{2}$ content in the composition resulted in the improved crystal growth $[6,14]$ and this phenomenon was observed in the GC3 and GC4 samples.

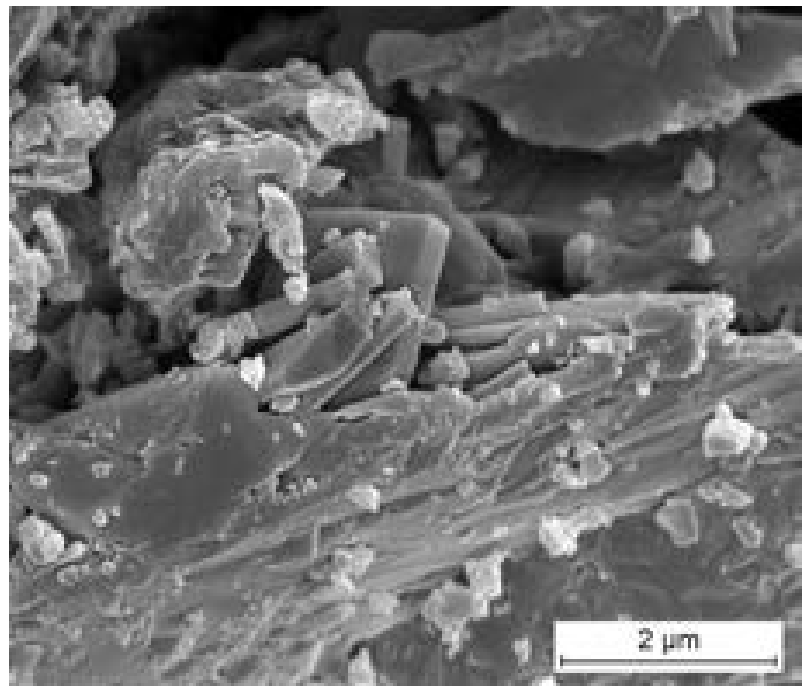

a)

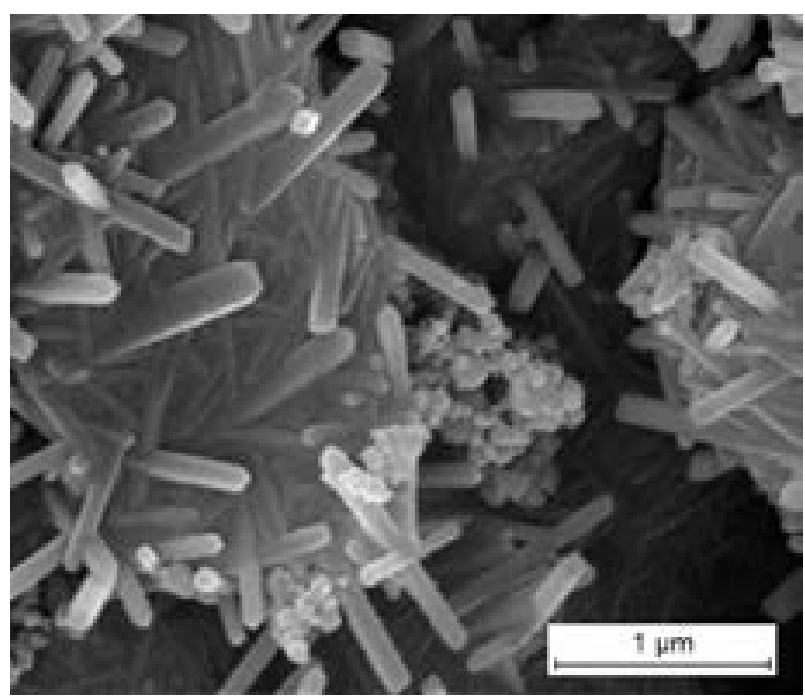

b)

Figure 6. The FESEM images of the needle-like fluorapatite crystal observed under higher magnification.
$\mathrm{CaF}_{2}$ as a nucleating agent is responsible for encouraging the nucleation of the crystals, thus leading to the crystal growth. Hence, the involvement of the high $\mathrm{CaF}_{2}$ addition in the glass network improved the crystallisation of the needle-like structure of the fluorapatite phase.

\section{CONCLUSIONS}

The apatite-mullite glass ceramic composition was fabricated from waste materials and the effect of the different $\mathrm{CaF}_{2}$ contents and heat treatment temperatures on the thermal, physical and structural properties of the apatite-mullite was studied. From this study, a high amount of $\mathrm{CaF}_{2}$ lowered both the $T_{g}$ and $T_{c}$. Besides, the best result is owned by the GC3 sample which contained 15 wt. $\%$ of $\mathrm{CaF}_{2}$ heat treated at $1000{ }^{\circ} \mathrm{C}$ since it produced a high density and an optimum percentage of linear shrinkage of the glass ceramic. In addition, the formation of fluorapatite and mullite phase, which is important for denture glass ceramics, was also optimum in the GC3 sample. The apatite phase formation in the glass ceramic samples was supported by the FTIR and FESEM analyses. Overall, the apatite-mullite glass ceramic composition fabricated from these waste materials is favourable for dental applications due to the involvement of the fluoride content which enhances the physical and structural properties of the resulting materials.

\section{Acknowledgements}

The financial support for this work was obtained from Inisiatif Putra Siswazah (IPS) and the Fundamental Research Grant Scheme (FRGS).

\section{REFERENCES}

1. Holand W., Rheinberger V., Apel E., yan't Hoen C., Hoeland M., Dommann A., Obrecht M., Mauth C., Graf-Hausner U. (2006): Clinical applications of glass-ceramics in dentistry. Journal of Materials Science: Materials in Medicine, 17, 1037-1042. doi: 10.1007/s10856-006-0441-y

2. Kaur G., Pandey O.P., Singh K., Homa D., Scott B., Pickrell G. (2013): A review of bioactive glasses: their structure, properties, fabrication and apatite formation. Journal of Biomedical Materials Research Part A, 102, 254-274. doi: 10.1002/jbm.a.34690

3. Chen X., Chen X., Brauer D.S., Wilson R.M., Hill R.G., Karpukhina N. (2014): Novel alkali free bioactive fluorapatite glass ceramics. Journal of Non-Crystalline Solids, 402, 172-177. doi: 10.1016/j.jnoncrysol.2014.05.025

4. Beall G.H. (1992): Design and properties of glass-ceramics. Annual Review of Materials Research, 22, 91-119. doi: 10.1146/annurev.ms.22.080192.000515

5. Hashmi M.U., Shah S.A., Umer F., Alkedy A.S. (2013): Effect of sintering temperature on microstructure and in vitro behaviour of bioactive glass ceramics. Ceramics-Silikáty, 57, 313-318. 
6. Clifford A., Hill R. (1996): Apatite-mullite glass-ceramics. Journal of Non-Crystalline Solids, 196, 346-351. doi: 10. 1007/BF00120298

7. Samuneva B., Dimitrov V., Kalimanova S., Gattef E., Hill R. (1998): Crystallization of gels in the apatite-mullite system. Journal of Sol-Gel Science and Technology, 13, 951-956. doi: 10.1023/A:1008691711234

8. Pollington S. (2011): Novel glass-ceramics for dental restorations. The Journal of Contemporary Dental Practice, 12, 60-67. doi: 10.5005/jp-journals-10024-1011

9. Stanton K.T., Hill R.G. (2005): Crystallisation in apatitemullite glass-ceramics as a function of fluorine content Journal of Crystal Growth, 275, e2061-e2068. doi: 10.1016/ j.jcrysgro.2004.11.266

10. Clifford A., Hill R., A Rafferty., Mooney P., Wood D., Samuneva B., Matsuya S. (2001): The influence of calcium to phosphate ratio on the nucleation and crystallization of apatite glass-ceramics. Journal of Materials Science: Materials in Medicine, 12, 461-469. doi: 10.1023/A 1011213406951

11. O’Flynn K.P., Stanton K.T. (2010): Nucleation and early stage crystallization of fluorapatite in apatite-mullite glassceramics. Crystal Growth \& Design, 10, 1111-1117. doi: $10.1021 / \operatorname{cg} 900868 \mathrm{t}$

12. Fathi H., Johnson A., van Noort R., Ward J.M., Brook I.M. (2005): The effect of calcium fluoride $\left(\mathrm{CaF}_{2}\right)$ on the chemical solubility of an apatite-mullite glass-ceramic material. Dental Material, 21, 551-556. doi: 10.1016/j.dental. 2004.07.018

13. Duminis T., Shahid S., Hill R.G. (2017): Apatite glass-ceramics: a review. Frontiers in Materials, 3, 1-15. doi: 10.3389/ fmats.2016.00059

14. Hill R., Patel M., Wood D.J. (1991). "Preliminary studies on castable apatite-mullite glass ceramics," in $4^{\text {th }}$ International Symposium on Ceramics in Medicine. London: Butterworth Heineman Ltd. doi: 10.1016/B978-0-7506-0269-3.50015-3

15. Farooq I., Imran Z., Farooq U., Leghari A., Ali H. (2012): Bioactive glass: A material for the future. World Journal of Dentistry, 3, 199-201. doi: 10.5005/jp-journals-10015-1156

16. Aitken B., Beall G.H. (1994). Material science and technology series. In: Cahn et al (eds) Glass-ceramics, 11, 269-294.

17. McMillan P.W. (1979). Glass-ceramics. $2^{\text {nd }}$ ed. London: Technology and Engineering. Academic Press.

18. Petersen P.E., Ogawa H. (2016): Prevention of dental caries through the use of fluoride-the WHO approach. Community Dental Health Journal, 33, 66-68. doi: 10.1922/CDH Petersen03

19. Brauer D.S., Karpukhina N., O’Donnell M.D., Law R.V., Hill R.G. (2010): Fluoride- containing bioactive glasses: effect of glass design and structure on degradation, $\mathrm{pH}$ and apatite formation in simulated body fluid. Acta Biomaterialia, 6, 3275-3282. doi: 10.1016/j.actbio.2010.01.043

20. Zaid M.H.M., Matori K.A., Sidek H.A.A., Kamari H.M., Yunus W.M.M., Wahab Z.A., Samsudin N.F. (2016): Fabrication and crystallization of ZnO-SLS glass derived willemite glass-ceramics as a potential material for optics applications. Journal of Spectroscopy, 2016, 1-7. doi: $10.1155 / 2016 / 8084301$

21. Wah L.C. (2016). Effects of heat treatment on structure and thermal diffusivities of $\mathrm{SiO}_{2}-\mathrm{Na}_{2} \mathrm{O}-\mathrm{Al}_{2} \mathrm{O}_{3}-\mathrm{CaO}-\mathrm{CaF}_{2}$ glass-ceramics from waste materials (master's thesis). Universiti Putra Malaysia, Malaysia.
22. Zaid M.H.M., Matori K.A., Sidek A.A., Wahab Z.A., Rashid S.S.A. (2017): Effect of sintering on crystallization and structural properties of soda lime silica glass. Science of Sintering, 49, 409-417. doi: 10.2298/SOS1704409Z

23. Jusoh W.N.W., Matori K.A., Zaid M.H.M., Zainuddin N., Khiri M.Z.A., Rahman N.A.A., Jalil R.A., Kul E. (2019): Effect of sintering temperature on physical and structural properties of Alumino-Silicate-Fluoride glass ceramics fabricated from clam shell and soda lime silicate glass. Results in Physics, 12, 1909-1914. doi: 10.1016/j.rinp.2019. 01.077

24. Rahman N.A.A., Matori K.A., Zaid M.H.M., Zainuddin N., Sidek H.A.A., Khiri M.Z.A., Jalil R.A., Jusoh W.N.W. (2019): Fabrication of alumino-silicate-fluoride based bioglass derived from waste clam shell and soda lime silica glasses. Results in Physics, 12, 743-747. doi: 10.1016/j. rinp.2018.12.035

25. Galvan-Ruiz M., Hernandez J., Banos L., Noriega-Montes J., Rodriguez-Garcia M.E. (2009): Characterization of calcium carbonate, calcium oxide, and calcium hydroxide as starting point to the improvement of lime for their use in construction. Journal of Materials in Civil Engineering, 21, 694-698. doi: 10.1061/(ASCE)0899-1561(2009)21:11(694)

26. Mohamad S.F., Mohamad S., Jemaat Z.B. (2016): Study of calcination condition on decomposition of calcium carbonate in waste cockle shell to calcium oxide using thermal gravimetric analysis. Journal of Engineering and Applied Sciences, 11, 9917-9921.

27. Huang N., Wang J. (2009): A TGA-FTIR study on the effect of $\mathrm{CaCO}_{3}$ on the thermal degradation of EBA copolymer. Journal of Analytical and Applied Pyrolysis, 84, 124-130. doi: 10.1016/j.jaap.2009.01.001

28. Khiri M.Z.A., Matori K.A., Zaid M.H.M., Abdullah C.A.C., Zainuddin N., Alibe I.M., Rahman N.A.A., Wahab S.A.A., Azman A.Z.K., Effendy N. (2019): Crystallization behavior of low-cost biphasic hydroxyapatite/ $\beta$-tricalcium phosphate ceramic at high sintering temperatures derived from high potential calcium waste sources. Results in Physics, 12, 638-644. doi: 10.1016/j.rinp.2018.12.025

29. Bansal N.P., Doremus R.H. (1986). Handbook of glass properties. New York: Academic Press.

30. Bellucci D., Cannillo V., Sola A. (2010): An overview of the effects of thermal processing on bioactive glasses. Science of Sintering, 42, 307-320. doi: 10.2298/SOS1003307B

31. Stanton K., Hill R. (2000): The role of fluorine in the devitrification of $\mathrm{SiO}_{2}-\mathrm{Al}_{2} \mathrm{O}_{3}-\mathrm{P}_{2} \mathrm{O}_{5}-\mathrm{CaO}-\mathrm{CaF}_{2}$ glasses. Journal of Material Science, 35, 1911-1916. doi: 10.1023/A: 1004710301219

32. Kokubo T., Ito S., Sakka S. (1986): Formation of a highstrength bioactive glass-ceramic in the system $\mathrm{MgO}-\mathrm{CaO}-$ $\mathrm{SiO}_{2}-\mathrm{P}_{2} \mathrm{O}_{5}$. Journal of Material Science, 21, 536-540. doi: $10.1007 / \mathrm{BF} 01145520$

33. Hill R., Wood D. (1995): Apatite-mullite glass-ceramics. Journal of Materials Science: Materials in Medicine, 6, 311-318. doi: 10.1007/BF00120298

34. Brauer D.S., Karpukhina N., Law R.V., Hill R.G. (2009): Structure of fluoride-containing bioactive glasses. Journal of Materials Chemistry, 19, 5629-5636. doi: 10.1039/ b900956f

35. Hayashi M., Nabeshima N., Fukuyama H., Nagata K. (2002): Effect of fluorine on silicate network for $\mathrm{CaO}-\mathrm{CaF}_{2}-\mathrm{SiO}_{2}$ and $\mathrm{CaO}-\mathrm{CaF}_{2}-\mathrm{SiO}_{2}-$ feox glasses. ISIJ International, 42 , 352-358. doi: 10.2355/isijinternational.42.352 
36. Salama S.N., Salman S.M., Darwish H. (2002): Effect of nucleation catalysts on crystallisation characteristics of aluminosilicate glasses. Ceramics-Silikáty, 46, 15-23.

37. Griggs J.A., Anusavice K.J., Mecholsky Jr J.J. (2002): Diversification and microstructural coarsening of a fluoridecontaining barium aluminosilicate glass. Journal of Material Science, 37, 2017-2020. doi: 10.1023/A:1015255300065

38. Ciftcioglu M. (1987): Measurement of agglomerate strength distribution in agglomerated powders. Iowa State Univ. of Science and Technology, Ames (USA).

39. Gorni G., Pascual M.J., Caballero A., Velázquez J.J., Mosa J., Castro Y., Durán A. (2018): Crystallization mechanism in sol-gel oxyfluoride glass-ceramics. Journal of Non Crystalline Solids, 501, 145-152. doi: 10.1016/j.jnoncrysol. 2018.01.031

40. Pallan N.F.B., Matori K.A., Hashim M., Lim W.F., Quah H.J., Fauzana A.N., Rosnah N., Khiri M.Z.A., Farhana S., Zainuddin N., Zarifah N.A., Nurzilla M., Zaid M.H.M., Loy C.W., Zamratul M.I.M. (2016): Preparation of $\mathrm{SiO}_{2}-$ $-\mathrm{Na}_{2} \mathrm{O}-\mathrm{CaO}-\mathrm{P}_{2} \mathrm{O}_{5}$ glass-ceramic from waste materials and heat treatment effects on its morphology. Materials Science Forum, 846, 189-192. doi: 10.4028/www.scientific.net/ MSF.846.189

41. Zarifah N.A. (2016). Physical and mechanical properties of hydroxyapatite reinforced with $45 \mathrm{~S} 5$ biocomposite (doctoral's thesis). Universiti Putra Malaysia, Malaysia.

42. Mirhadi B., Mehdikhani B. (2012): Effect of calcium fluoride on sintering behavior of $\mathrm{SiO}_{2}-\mathrm{CaO}-\mathrm{Na}_{2} \mathrm{O}-\mathrm{MgO}$ glass-ceramic system. Processing and Application of Ceramics, 6, 159-164. doi: 10.2298/PAC1203159M

43. Wilson A.D., Crisp S., Prosser H.J., Lewis B.G., Merson S.A. (1980): Aluminosilicate glasses for polyelectrolyte cements. Industrial \& Engineering Chemistry Product Research and Development, 19, 263-270. doi: 10.1021/ i360074a027

44. Riaz M., Zia R., Mirza A., Hussain T., Bashir F., Anjum S. (2017): Synthesis, characterization of $\mathrm{CaF}_{2}$ doped silicate glass-ceramics. Materials Science and Engineering: C, 75, 872-876. doi: 10.1016/j.msec.2017.02.141

45. Syamimi N.F., Matori K.A., Lim W.F., Sidek H.A.A., Zaid M.H.M. (2014): Effect of sintering temperature on structural and morphological properties of europium (III) oxide doped willemite. Journal of Spectroscopy, 2014, 1-8. doi: 10.1155/2014/328931

46. Rafferty A., Clifford A., Hill R., Wood D., Samuneva B., Dimitrova-Lukacs M. (2000): Influence of fluorine content in apatite-mullite glass-ceramics. Journal of the American Ceramic Society, 83, 2833-2838. doi: 10.1111/j.1151-2916. 2000.tb01640.x

47. Galliano P.G., Porto López J.M. (1995): Thermal behaviour of bioactive alkaline-earth silicophosphate glasses. Journal of Materials Science: Materials in Medicine, 6, 353-359. doi: 10.1007/BF00120304

48. Bogdanov B.I., Pashev P.S., Hristov J.H., Markovska I.G. (2009): Bioactive fluorapatite-containing glass ceramics. Ceramics International, 35, 1651-1655. doi: 10.1016/j.ceramint.2008.07.021

49. Newman A.C.D. (1968): Apparatus for separating fluorine from aluminosilicate by pyrohydrolysis. Analyst, 93, 827 . doi: 10.1039/AN9689300827
50. Al-Bader R.M., Ziadan K.M., Al-Ajely M.S. (2015): New glass compositions based on calcium-fluoroaluminosilicate for dental composite. Journal of Advances Chemistry, 10, 2743-2752.

51. Hong Z., Merino E.G., Reis R.L., Mano J.F. (2009): Novel rice-shaped bioactive ceramic nanoparticles. Advanced Engineering Materials, 11, B25-B29. doi: 10.1002/adem. 200800378

52. Knubovets R. (1993): Structural mineralogy and properties of natural phosphates. Chemical Engineering Journal, 9, 161-216.

53. Kuzielová E., Palou M., Lokaj J., Kozánková J. (2008): Bioactivity investigation of glass and glass ceramics in $\mathrm{Li}_{2} \mathrm{O}-\mathrm{SiO}_{2}-\mathrm{CaO}-\mathrm{P}_{2} \mathrm{O}_{5}-\mathrm{CaF}_{2}$ system. Advances in Applied Ceramics, 107, 203-209. doi: 10.1179/174367608X263340

54. Abdelghany A.M., Elkashef I.M., ElBatal H.A. (2018): Manifestation and role of $\mathrm{B}_{2} \mathrm{O}_{3}$ in high lead containing silicate glasses. Silicon, 10, 1103-1110. doi: 10.1007/s12633017-9577-2

55. Montazeri N., Jahandideh R., Biazar E. (2011): Synthesis of fluorapatite-hydroxyapatite nanoparticles and toxicity investigations. International Journal of Nanomedicine, 6 , 197-201. doi: 10.2147/IJN.S15461

56. Feng D., Zhu Y., Li F., Li Z. (2016): Influence investigation of $\mathrm{CaF}_{2}$ on the LAS based glass-ceramics and the glass ceramic/diamond composites. Journal of the European Ceramic Society, 36, 2579-2585. doi: 10.1016/j.jeurceramsoc. 2016. 03.020

57. Kim C.Y., Clark A.E., Hench L.L. (1989): Early stages of calcium-phosphate layer formation in bioglasses. Journal of Non-Crystalline Solids, 113, 195-202. doi: 10.1016/00223093(89)90011-2

58. Yang Z., Lin Q., Lu S., He Y., Liao G., Ke Y. (2014): Effect of $\mathrm{CaO} / \mathrm{SiO}_{2}$ ratio on the preparation and crystallization of glass-ceramics from copper slag. Ceramics International, 40, 7297-7305. doi: 10.1016/j.ceramint.2013.12.071

59. Peitl O., Zanotto E.D., Hench L.L. (2001): Highly bioactive $\mathrm{P}_{2} \mathrm{O}_{5}-\mathrm{Na}_{2} \mathrm{O}-\mathrm{CaO}-\mathrm{SiO}_{2}$ glass-ceramics. Journal of NonCrystalline Solids, 292, 115-126. doi: 10.1016/S0022-3093 (01)00822-5

60. Hamasaki T., Eguchi K., Koyanagi Y., Matsumoto A., Utsunomiya T., Koba K. (1988): Preparation and characterization of machinable mica glass-ceramics by the sol-gel process. Journal of American Ceramics Society, 71, 11201124. doi: 10.1111/j.1151-2916.1988.tb05802.x

61. Kansal I., Goel A., Tulyaganov D.U., Shaaban E.R., Ribeiro M.J., Ferreira J.M. (2009): The effect of fluoride ions on the structure and crystallization kinetics of $\mathrm{La}_{2} \mathrm{O}_{3}$-containing diopside based oxyfluoride glasses. Ceramics International, 35, 3489-3493. doi: 10.1016/j.ceramint.2009.04.011

62. Hoch M., Nair K.M. (1976): Densification characteristics of ultrafine powders. Ceramurgia International, 2, 88-97. doi: 10.1016/0272-8842(85)90055-0

63. Mazdiyasni K.S., Lynch C.T., II J.S. (1967): Cubic phase stabilization of translucent yttria-zirconia at very low temperatures, Journal of American Ceramics Society, 50, 532-537. doi: 10.1111/j.1151-2916.1967.tb14989.x 